\title{
CAMA
}

Centre for Applied Macroeconomic Analysis

\section{Global Climate Change Mitigation: Strategic Incentives}

\section{CAMA Working Paper 10/2018 February 2018}

Sigit Perdana

Business School, The University of Western Australia

\section{Rod Tyers}

Business School, The University of Western Australia, Research School of Economics, ANU and

Centre for Applied Macroeconomic Analysis, ANU

\section{Abstract}

Central to global agreement on carbon emissions are strategic interactions amongst regions over carbon tax implementation and the benefits to be shared. These are reexamined in this paper, in which benefits from mitigation stem from a meta-analysis that links carbon concentration with region-specific measures of economic welfare. Implementation costs are then drawn from a highly disaggregated model of global economic performance. Multiplayer games are then constructed, the results from which are sensitive to embodied temperature scenarios and discount rates but robustly reveal that the US and China would be net gainers from unilateral implementation in net present value terms. The dominant strategy for all other countries is to free ride. Net gains to the three large economies are bolstered by universal adoption, which could be induced by affordable side payments. Yet the revealed downside is that net gains to all regions are negative for at least two decades, rendering commitment to abatement politically difficult. 


\section{Keywords}

Climate change, Carbon taxation, Global dynamic general equilibrium analysis

\section{JEL Classification}

F47, F64, Q34, Q54

\section{Address for correspondence:}

(E) cama.admin@anu.edu.au

ISSN 2206-0332

The Centre for Applied Macroeconomic Analysis in the Crawford School of Public Policy has been established to build strong links between professional macroeconomists. It provides a forum for quality macroeconomic research and discussion of policy issues between academia, government and the private sector.

The Crawford School of Public Policy is the Australian National University's public policy school, serving and influencing Australia, Asia and the Pacific through advanced policy research, graduate and executive education, and policy impact. 


\title{
Global Climate Change Mitigation: Strategic Incentives*
}

\author{
Sigit PERDANA \\ Business School, \\ The University of Western Australia \\ Rod TYERS \\ Business School \\ The University of Western Australia, \\ Research School of Economics, \\ Centre for Applied Macroeconomic Analysis (CAMA) \\ The Australian National University
}

Revised April 2018

Keywords:

climate change, carbon taxation, global dynamic general equilibrium analysis

JEL Codes:

F47, F64, Q34, Q54

Author contact details:

Sigit Perdana

UWA Business School,

Crawley, WA 6009

Australia

sigit.perdana@ research.uwa.edu.au

Rod Tyers

Winthrop Professor of Economics

UWA Business School

rod.tyers@uwa.edu.au

\footnotetext{
* Funding for the research described in this paper is from the Indonesian Endowment Fund for Education. Thanks for suggestions and useful discussions on the topic are due to Ken Clements, Bei Li, Michael McLure, Peter Hartley and Richard Tol along with session participants at the $40^{\text {th }}$ International Conference of the International Association Energy Economics (IAEE), June 2017, Singapore, and the 2017 National CGE Workshop, Centre for Policy Study (CoPS), August 2017, Melbourne Australia.
} 


\title{
Global Climate Change Mitigation: \\ Strategic Incentives
}

\begin{abstract}
Central to global agreement on carbon emissions are strategic interactions amongst regions over carbon tax implementation and the benefits to be shared. These are re-examined in this paper, in which benefits from mitigation stem from a meta-analysis that links carbon concentration with region-specific measures of economic welfare. Implementation costs are then drawn from a highly disaggregated model of global economic performance. Multiplayer games are then constructed, the results from which are sensitive to embodied temperature scenarios and discount rates but robustly reveal that the US and China would be net gainers from unilateral implementation in net present value terms. The dominant strategy for all other countries is to free ride. Net gains to the three large economies are bolstered by universal adoption, which could be induced by affordable side payments. Yet the revealed downside is that net gains to all regions are negative for at least two decades, rendering commitment to abatement politically difficult.
\end{abstract}

\section{Introduction}

Mitigating global warming has been focal in negotiations toward the Kyoto Protocol and the more recent the climate convention on COP 21 Paris (Cooper et al. 2016; Dimitrov 2016). Current evidence suggests that these have not been effective in mobilizing all countries to reduce emissions. ${ }^{1}$ This ineffectiveness can be explained, first, by disagreement over the scale of mitigation costs and who should bear them (Mahapatra \& Ratha 2017), reflecting the inevitable trade-off between effective mitigation and growth performance. Second, voluntary agreement in the presence of a "tragedy of the commons" is problematic (Clarke \& Waschik 2012). Coordination through artificial markets for carbon emissions have thus far shown only modest and localised effect, while such emission reductions as have occurred have stemmed largely from exogenous moderation in economic activity. ${ }^{2}$ Even the COP Paris 21 "pledge and review" commitments are claimed to be ineffectual (Falkner, Stephan \& Vogler 2010). Most concerning has been tardiness in some large economies in the implementation of emission controls of sufficient scale to encourage reciprocity in the emerging and poorer economies, whose future growth will contribute most substantially to the incremental burden of mitigation.

\footnotetext{
${ }^{1}$ Victor (2011) refers to the problems of the ineffective international commitment as "the global warming gridlock".

${ }^{2}$ The implementation of the European Trading Scheme (ETS), in particular, tended to advantage the Kyoto nonbinding parties, while its volatile market mechanisms failed to offer reliable emission control incentives (Richstein, Chappin \& de Vries 2015).
} 
It is commonly regarded that the common property characteristic of global warming, in particular, leaves voluntary mitigation policies depending on altruism, which is declared to be insufficient for success at the scale required (Fehr \& Gächter 2000). The political preference to free ride is strong, amongst other things underlying the failure of the US Congress to ratify the Kyoto Protocol (Hovi, Sprinz \& Bang 2010). In addition, there is the issue of carbon leakage. Poorly implemented and heterogeneous incentives have already triggered the reallocation of dirty industries to comparatively poor countries with weak domestic environmental policies (Burniaux \& Martins 2012). Yet all these perspectives rest on the presumption that, for no country or cohesive economic region is there a unilateral gain from mitigation policy. Moreover, even if the very large economies did perceive unilateral gains, those would not be large enough to justify side payments that might induce free riders to participate. These are empirical questions, answers to which this paper contributes.

The particular literature complemented is that addressing these strategic interactions, led by Nordhaus (2015) and the follow- up studies by Sælen (2016) and Hovi et al. (2017). Nordhaus uses the Coalition-DICE Model and an "evolutionary algorithm approach" to examine the potential for international "clubs" that implement uniform carbon taxes with target prices that range between 12.5 USD and 100 USD per ton of $\mathrm{CO} 2$. A uniform carbon pricing regime without trade sanctions is shown to lead only to a non-cooperative equilibrium with minimal abatement. It is concluded that non-participation is the best strategy even for the larger key players: China, the US and the EU. More generally, these studies suggest the need for penalties in the form of trade tariffs in order that stable coalitions should be formed. ${ }^{3}$

This paper commences with a detailed meta-analysis of benefits from mitigation that link carbon emissions to average surface temperature and then to region-specific changes in economic welfare. These results are then combined region-specific mitigation costs that are calculated using a dynamic model of the global economy that is more highly disaggregated across products and regions than has been used in the previous studies. The level of disaggregation is particularly useful in capturing the interactions across regions that operate through changes in the terms of trade and the global distribution of investment that, in turn, stem from the implementation of mitigation policies alone. Net costs thus calculated are then

\footnotetext{
${ }^{3}$ Numerous alternative approaches have been offered that are not within our present scope. Aldy et al. (2003) provide a review. In particular, McKibbin and Wilcoxen (2002) offer a hybrid approach directed at tackling the inefficiency of the tradeable permit system and the political impracticability of an uncoordinated carbon price. Model regimes emphasising linkages and dominant factors are suggested by Stewart et al. (2013). Climate policy "clubs" that can be large enough to influence the global carbon price were initially suggested by Cooper (1998; 2001; 2007) and further examined by Weitzman (2015).
} 
combined with the results from the meta-analysis to construct matrices of regional pay-offs in 2015 present values that are amenable to analysis as multi-player normal form games.

For reasonable ranges of parameters such as the discount rate, critical mass turns out to be smaller than the individual contributions of the two largest economies, the US and China, so that they would be unilateral gainers from the adoption of carbon taxation. They contribute large enough shares of global carbon emissions that the gains from their abatement alone exceed their mitigation costs. It follows, then, that a "climate club" comprising the US, China, and Europe, would also be a unilateral gainer. Moreover, their collective net gains in present value terms prove sufficient to finance side payments that are would induce universal adoption. Nonetheless, the net gains do not turn positive in any region for two decades, rendering these policy outcomes politically difficult to achieve.

Section 2 briefly reviews the substantial prior literature on strategic interactions influencing potential agreement on climate policy. Section 3 introduces the global modelling of mitigation costs and their distribution and section 4 reviews studies that quantify the climate impacts of different levels of mitigation and their consequences for global economic welfare, combining these in a meta-analysis. Section 5 uses the results from previous two sections to construct multiplayer normal form games and to derive policy-relevant equilibria. The section 6 then concludes and summarizes the research findings.

\section{Climate Policy Interaction and Strategic Behaviour}

Reflecting the widespread concern over human-induced climate change over many decades, the literature on these topics is both rich and vast. Here we mention only those studies most relevant to the research to be subsequently presented, with the purpose of clarifying key points of difference.

\subsection{Uniform Carbon Pricing}

A major concern in studies like this is the prospect of regionally heterogeneous climate policies. Accounting for this is a herculean task for analysts and one that we will avoid, choosing instead to imagine that regional policies have equivalents in carbon taxation and that the policy choice is simply whether or not to implement those policies at the rate of US\$ 20 per tonne. Support for this is offered by Barrett (2002) and Cramton et al. (2015), who see uniform carbon taxation as "dynamically efficient" by virtue of its transparency and its 
minimisation of "carbon leakage". 4 Such taxes are seen as easier to regulate and to coordinate than permit trading systems (Avi-Yonah \& Uhlmann 2009) since the global agreement is unidimensional, looking beyond region-specific quantities and prices.

Moreover, unlike carbon trading structures uniform carbon taxation does not create financial instruments, the quality of which is opaque and heterogeneous, leading to excess volatility and potential market failure (Shiller1981; LeRoy 2005). Accordingly, carbon taxation reduces emissions even where there is high risk and volatility derived from other sources (McKibbin, Morris \& Wilcoxen 2008). ${ }^{5}$

\subsection{Strategic Interactions with Uniform Carbon Pricing}

The most prominent work that models strategic interactions at the global level is represented in the suite of articles by Nordhaus \& Yang (1996), Nordhaus \& Boyer (1999), Nordhaus \& Yang (2006), Nordhaus (2010; 2011; 2014). It employs two models of the global economy, namely DICE, which is a global and dynamic, and RICE, in which the world is divided into several regions. These models integrate the climate sector with the global economy, and each country is assumed to produce a single commodity for either consumption or investment based on Cobb Douglas technology. In particular, Nordhaus (2015) assesses climate policy coalitions and examines the role of trade sanctions, imposed for stability, using the CoalitionDICE (C-DICE) model. In this work macroeconomic, bilateral trade and environmental data are used to determine each country's strategic incentive to join a coalition of high abatement countries. Payoffs are impacts on net national income and countries interact on carbon prices and punitive tariffs. Dynamic stability is not considered, however, despite the incentives facing countries changing inevitably as their growth paths and economic structures change.

Sælen (2016) and Hovi et al (2017) extend the work of Nordhaus by considering the potential of transfer payments to induce full participation. They use a simple and stylized binary decision model with empirical foundations, which includes population and GDP levels, associated emissions and vulnerability to climate change. Sælen's results indicate that there is substantial potential for side payments to facilitate an effective club. Hovi et al. extend Sælen's work and offer a more regionally disaggregated approach emphasising the

\footnotetext{
${ }^{4}$ Dynamic efficiency addressed by Aldy et al. (2003) as a criterion to evaluate global climate policy regimes. An efficient policy achieves maximum aggregate net benefit, relaxing the Pareto efficiency criterion to the level of Kaldor-Hicks which emphasises potential with appropriate transfers.

${ }^{5}$ All this said, carbon taxes are not without their detractors. See, for example, Schmalensee (1998), who emphasises uncertainty and regional heterogeneity of outcomes, Bolton \& Ockenfels (2000) and Kraft-Todd et al. (2015) who posit a coordination game structure in which first implementers lose. Golub (2013) analyses the extent of carbon leakage under the alternative of a permit trading system.
} 
importance of initiation by the large emitters, particularly the US and the EU. They classify each country into two types, reluctant or enthusiastic, based on assumptions about intrinsic motivation to start a climate agreement.

A number of points of difference arise between these prior works and ours to follow. First, we follow the critique of Böhringer et al. (2017) and build on the innovative work of the Nordhaus team by using a model with fully endogenous capital growth paths and a level of disaggregation that enables the capture of both the leakage of emissions through trade in energy products and the effects of terms of trade changes due to carbon taxation in one region on the net gains achieved by others. One result of this approach is that the costs of participation differ significantly between regions and over time, as do the benefits at the regional level that are derived from our meta-analysis. We capture all the relevant dynamics and regional interactions but make the assumption that regional governments are able to precommit to mitigation policies at the outset, depending on their assessments of discounted net present values of economic gains over the coming 50 years.

As to coalition stability, we recognise that self-enforcing structures (Barret 1994; 2003) are required. The more members the greater are incentives to free ride. ${ }^{6}$ If there are regions that derive unilateral benefits from implementing abatement policy but benefit further if other regions join, then coalition stability is readily retained by the conditionality of side payments. ${ }^{7}$ We give emphasis to positive side payments, rather than punitive tariffs, following Sælen (2016) and Hovi et al (2017), but evaluate the affordability of side payments by comparing them with the measured present value of the net benefits from global abatement that accrue to the initiating region. ${ }^{8}$ In the interests of analytical economy, however, we imagine that there is only one policy choice, as between the status quo and a US\$20 carbon tax, and that governments commit as of 2015 to a once and for all policy choice based on the net present value of net regional benefits. We begin with the modelling of costs in the section to follow.

\footnotetext{
${ }^{6}$ This is a condition called the "small paradox" that makes free riding become inevitable (Carraro and Siniscalco 1993).

${ }^{7}$ See Carraro and Siniscalco (1998), Martimort and Sand-Zantman (2015) and Caparrós \& Péreau (2017).

${ }^{8}$ We acknowledge numerous applications of Nash's restricted stability condition in climate conflict studies, such as those by Howard (1971), Selbirak (1994), Pittel and Rubbelke (2008), Decanio \& Fremstad (2013) and Madani (2013).
} 


\section{Estimating the Future Economic Cost of Mitigation}

This work proceeds in two phases. First, a dynamic model of the global economy is adapted to the assessment of carbon taxation at the regional level, the structure chosen is described and the database used is then summarised. The model is then applied to the construction of a baseline projection of global economic performance through 2050, during which a range of mitigation scenarios is considered.

\subsection{Modelling Global Economic Performance with Carbon Taxation}

A dynamic, global general equilibrium model is used that is based primarily on the global dataset of the Global Trade Analysis Project (GTAP-7). ${ }^{9}$ It includes five primary factors: land, natural resource, skilled and unskilled labor and capital. The full set of 57 commodities is condensed into 12, amongst which the energy sector consists of coal, crude oil, gas and petroleum products. Eight regions are included: Indonesia, Australia, China, Japan, and the USA, the European Union (EU), ASEAN and rest of the world (ROW). ${ }^{10}$

\section{The Model}

An adaptation of the Gdyn-E model of Golub (2013) is used. ${ }^{11}$ The embodied dynamics offer better treatment of long-run projections by accommodating current account imbalances, codified international capital mobility, capital accumulation and an adaptive adjustment theory of investment at the country or regional level. Populations and labor supplies are projected exogenously to 2050, consistent with Fouré, Bénassy-Quéré and Fontagné (2010). Changes in factor and input productivity by industry, and in risk-related investment premia, are initially calibrated by making them endogenous in a "pre-base" simulation with exogenous paths for global GDP and investment by region that are consistent with IMF (2015). A subsequent change of closure renders productivity and investment premia exogenous and investment and GDP endogenous in all policy experiments.

Relative to the Golub (2013) version, our applications have required considerable recoding of the model and modifications to the original GDyn-E database, as well as the construction of a distinct baseline projection of the global economy that incorporates feasible demographic and

\footnotetext{
${ }^{9}$ An early but complete description of the database is in hard copy as Narayanan and Walmsley (2008).

${ }^{10}$ Details as to the aggregation adopted are listed in the Appendix, Tables A1, A2, and A3 respectively. A more complete appendix is available from the authors.

${ }^{11}$ This model merges GTAP Dynamic (Ianchovina \& Walmsley 2012) with GTAP-E, a static model that expands on the energy industries and fuels, and is equipped with complete emission coefficients for each industry. GTAP-E is based in turn on the original GTAP comparative static model (Hertel 1998) and the energy model of Buniaux and Truong (2002).
} 
technological scenarios. Critical to the scenarios constructed is the productivity performance in China, which is the single largest carbon emitter, and in the base period at least, the most rapidly expanding economy. The baseline, about which more is said in the next subsection, assumes slower productivity growth than Golub (2013) and a graduated slowing beyond the base year.

Our adaptation retains neoclassical perfect- competition, Armington product differentiation, and, essential for long run projections, non-homothetic consumer demand. It also retains the nested Constant Elasticity of Substitution (CES) production structure, illustrated in the Appendix (Figure A1), with its unique energy sector substructure. The uppermost nest level is gross production, which for good $i$ can be presented in the CES form:

$$
y_{i}=\left[\sum_{j} \alpha_{i j} v_{i j} \frac{\sigma-1}{\sigma}+\alpha_{V A E} v a e_{i j}^{\frac{\sigma-1}{\sigma}}\right]^{\frac{\sigma}{\sigma-1}}
$$

Final output depends on net substitution between an energy value added sub-nest, vae, and sub nest of intermediate inputs $v$, while $\sigma$ depicts the elasticity of substitution between them. Energy, as feedstock, enters as the intermediate input, while the energy value added sub nest embodies complementarity between capital and the energy nest. The adapted model uses five types of energy input: coal, crude oil, petroleum products, gas and electricity, the latter, in turn depending on inputs comprising the more basic forms. Inter-fuel and fuel to composite substitution are embodied in all nests in the production structure. As a composite production input, energy is divided between electricity and non-electricity, the later comprising coal and non-coal input groups. Aggregated energy complemented with capital, then produces a CES energy capital composite, which in turn joins with primary factor value added in contribution to final production.

Private household consumption applies the non-homothetic constant difference of elasticities of substitution (CDE) demand system. The function follows the approach of Hanoch (1975), representing non-homothetic preferences realistically and ensuring that the pattern of consumption changes as the income grows. The consumption nest is illustrated in the Appendix (Figure A2). Government consumption separates energy and non-energy commodity groups, again using CES nests, as illustrated in the Appendix (Figure A3). In capturing international capital mobility the model tracks investment flows and international factor income payments, indirectly simulating portfolio management in each region where 
portfolios comprise the home and foreign financial assets, representing indirect claims on firm physical capital in the home economy and abroad. Portfolios expand each year with the addition of purchases financed by home saving. ${ }^{12}$ Assets are assumed to be differentiated across regions so their yields on assets differ, with a tendency for those yields to converge due to return-seeking investment flows. Country risk effects are exogenous, presented by exogenous premia on yields that are calibrated from investment projections via a pre-base simulation, as indicated previously.

Emission coefficients are calculated based on energy consumed by firms, households and government. In this application only carbon dioxide $\left(\mathrm{CO}_{2}\right)$ emissions from energy consumption are accounted for, representing carbon released from the burning of coal, gas, oil and their derivative products. Regional emissions are then proportional to the sum of all energy used, as embodied in both locally consumed domestic and imported goods, in each case adjusted via process-specific emissions data. This procedure follows the study by Lee (2008) and the values emerging are consistent with GTAP-7 emission database and with the 1996 IPCC Guidelines. The $\mathrm{CO}_{2}$ emissions are calculated as:

$$
\begin{gathered}
C O_{2, i j r}=\left(\frac{F C_{i j r} \cdot C C_{i j r} \cdot\left(1-C S T_{i j r}\right) \cdot E F_{i} \cdot F O C_{i} \cdot(44 / 100)}{1000}\right) \\
i \in E G Y C O M M, j \in A L L S E C, r \in R E G
\end{gathered}
$$

These emissions (in gigagrams, or $\mathrm{Gg}$ ) are the products of fuel consumption ( $F C$, measured in 1000 tonnes of oil equivalent, or 1000 toe) in the form of six energy commodities (coal, crude oil, gas and gas products, petroleum products and electricity) and the respective emission conversion factors. First, the variable $C C$ is the conversion coefficient (in terajoules or TJ per 1000 toe) from toe to TJ. CST is the ratio of carbon storage, so that (1-CST) is the ratio of carbon released. The variable $E F$ is the emission factor (tonnes of carbon per TJ), and FOC symbolizes the fraction of carbon oxidized from each energy commodity. ${ }^{13}$ The calculation is based on the IPCC (1996) guidelines, and all subsequent factors follow this standard. The estimated total emissions from fossil fuel combustion amount to 37,214 million metric ton of petroleum equivalent in the database of our study.

\footnotetext{
${ }^{12}$ To minimize portfolio complexity, the model has all foreign assets held via a global trust. This way each portfolio has only two elements, home capital and foreign capital in the form of units in the global trust. ${ }^{13}$ See Lee (2008) for commodity-specific value of CC, EF and FOC. The value of CST derived from IEA/OECD Energy Balance Report 2006.
} 


\section{Emissions in the Database}

Among the 21 aggregated regions, the USA emitted the most CO2 in 2015, followed by China and the European Union. The USA emitted around 7,348 million tonnes of carbon or 20 per cent of global emissions. China emitted 6,958 million tonnes or 18.6 per cent of the global total. These large shares ensure that the USA and China are the most significant regions in affecting carbon emission control. Emissions released by countries such as Japan, India, Australia and Indonesia all contribute less than five per cent.

The electricity sector is the largest single user of raw energy commodities and so it is also the largest emitter. Around 50 per cent of global emissions is from this source, of which more than 70 per cent is due to the burning of coal. The emissions from burning gas contribute about a fifth, while smaller contributions are from petroleum used in energy-intensive industries and transport. Emissions from manufacturing industries are not significant at the global level, contributing only three per cent of the total. ${ }^{14}$ Emissions from private consumption stem mostly from the burning of petroleum products that, for many regions, come from imports. Petroleum usage contributes about 90 per cent of total private emissions in each region, except China. There, at least in the earlier 2000s, coal consumption by private households contributed half the emissions from private consumption. Indeed, China was the world's largest consumer and importer of coal, making China's mitigation strongly dependent on fuel substitution.

\subsection{Baseline Mitigation Costs and Carbon Taxation Scenarios}

The model is solved over the period 2015-2050 with a focus on the effects of carbon taxation on measures of economic welfare and the associated interactions between economies through trade and investment flows. A baseline projection is first constructed. It is designed to represent the path of global economy with no additional carbon taxation, nor any other changes to government intervention. ${ }^{15}$

\footnotetext{
${ }^{14}$ Refer to the Appendix for sectoral contributions to global emissions.

${ }^{15}$ Recent emission mitigation action has taken the form of technological improvements in fossil fuel energy usage in the production process for several countries. Technical improvement rates are, accordingly, represented in our baseline simulation for the cases of Japan, USA and EU, as well as China and India. The energy intensity rates used are based on the IEA ETP 2010 Report on each Region's energy intensity improvement from 19902007. The rates are listed in table A4 in the appendix.
} 


\section{The Baseline}

The exogenous drivers of growth are changes to populations and to total factor productivity by industry. The global population is set to grow at a positive yet declining rate, following Fouré, Bénassy-Quéré and Fontagné (2013). Changes through time in productivity and in regional investment premia are calibrated by constructing a "pre-base" simulation to 2050 in which these are specified as endogenous, while the corresponding paths of real GDP and real investment in each region are made exogenous so as to yield smooth performance paths consistent with projections by the IMF (2016). In all subsequent simulations this is reversed, so that the same exogenous paths are used for productivity and investment premia while investment and GDP are then endogenous.

The productivity changes have two components. The main one is a national productivity shifter, used in the pre-base simulation that supplements the implied level of technical change in each region. There is also a set of pre-determined industry-specific productivity growth paths that, in combination with the non-homotheticity of demand, drive changes in economic structure through time. The risk premia apply to yields on capital that drive the allocation of investment between countries. They capture the extent to which non-modeled factors limit investment in some regions even where such things as low wage growth might otherwise make these attractive destinations.

The resulting baseline projection yields paths of real regional GDP growth rates that are illustrated in the Appendix (Figure A4). The overall Asian economy grows at around four to five per cent per year while advanced economies retain lower yet stable growth. China's growth rate declines from more than seven per cent per year in the early years to less than five per cent per year by 2050. Since this growth rate remains comparatively high, China is prominent throughout as carbon emitter. According to this projection, by 2020, it would surpass the US as the biggest emitter in the world. By 2050, China would contribute 16.7 per cent of global emissions, followed by emerging India with 12.1 per cent.

Because the projection holds policy variables constant in ad-valorem terms it is not consistent with proposed carbon reduction targets at the regional level. For the USA, the Obama government chose to target a reduction of a substantial 25-28 per cent relative to $2005 .{ }^{16}$ Yet the USA mitigation target is less aggressive than other regions. China's target is a reduction

\footnotetext{
${ }^{16}$ https://www.whitehouse.gov/the-press-office/2015/03/31/fact-sheet-us-reports-its-2025-emissions-targetunfecc.
} 
by 40-45 per cent, per unit of GDP, by the year 2020 and 60-65 per cent by the year 2030 . Japan uses 1990 as the baseline year with 25 per cent reduction target; while the EU has a reduction target of 40 per cent by 2030. Even Indonesia, which is a substantial emitter amongst developing countries, is planning a reduction of $26-41$ per cent. Our simulations with carbon taxes therefore embody variations on these commitments but are compared against a baseline in which they do not occur.

\section{Scenarios}

Several scenarios are constructed to examine the global and regional effects of carbon taxation. Since GDP is a measure of the total income generated within an economy, the immediate cost of mitigation is calculated based on the deviation of regional real GDP from baseline levels. ${ }^{17}$ To make the task manageable, the carbon tax rate considered in all regions is restricted to 20 USD per tonne. This rate is central among those discussed and it has been proven to be sufficient to achieve static targets in numerous countries, including China's 65 per cent declared reduction by $2030 .{ }^{18}$

Importantly, the simulations apply the tax at the point of emission, so it is borne predominantly by fuel users downstream rather than by upstream fuel producers. The tax applies to the amount of fuel consumed, which makes it most significant for electricity generators, though it is also important for energy-intensive activities in other sectors, such as refineries, chemical manufacturing, and transportation. The fuel prices facing each industry have two components: the pre-existing ad volarem production tax $(\tau)$ and the new carbon tax $(\varphi)$, where the latter is a specific tax based on each industry's carbon emissions per unit of output. The market price of goods, $P_{i j r}^{M}$, that use as inputs fuel type $i$ ( coal, crude oil, gas and petroleum) in sector $j$ and region $r$, therefore depends on the agents' price, $P_{i j r}^{P}$, according to:

$$
P_{i j r}^{M}=\left(1+\tau_{j r}\right) P_{i j r}^{P}+\varphi_{i j r}
$$

Clearly, there are as many unilateral carbon tax implementation scenarios as there are regions defined in the model. Although all of these are implemented, it is not possible to represent all of the emerging results. For now, we turn to the case of global, or universal, implementation.

\footnotetext{
${ }^{17}$ This treatment is an advance over the identical abatement cost parameter of the DICE_C model used by Nordhaus (2015).

${ }^{18}$ A USD 20 per tonne $\mathrm{CO}_{2}$ tax rate could meet Indonesian's ambitious target of 26-41 per cent, based on Unilateral Carbon Taxation in Indonesia: Economic Implications (Perdana \& Tyers 2016).
} 


\section{Carbon Taxation Globally}

When all regions in the world commit to the USD 20 carbon tax, the effects are generally but slightly contractionary. Figure 1 exhibits these negative effects on real GDP levels. The imposition of tax and mitigation responses causes economic restructuring both regionally and globally (Ekins \& Speck 1999). This alters the terms of trade between regions with the effect that some regions enjoy gains that more than offset the cost of implementing the tax. Japan and the European Union, in particular, enjoy expansions in their GDP levels, relative to the baseline. ${ }^{19}$ This departs from what would be observed had either region implemented the tax unilaterally, in which case their real GDP growth would be curtailed relative to the baseline. The difference is due in part to their comparatively strong baseline emission controls, which reduce the burden of the eventual tax and to their assumed relative productivity performance paths in energy-intensive industries. These cause the rate of return on future investment in these regions to grow relative to other regions subject to the tax and so they enjoy faster capital growth.

The Chinese economy suffers a comparatively large loss of output relative to the baseline, which grows rapidly in the early years, peaks at more than two per cent in the late 2020s and recedes thereafter. Clearly, some of the costs to the Chinese economy are eventually offset by terms of trade gains associated with changes in energy-intensive activities in other regions and China's continuing comparatively strong overall productivity growth. Other regions also experience negative GDP deviations. Unlike Japan and the European Union, these regions bear significant losses due to the tax, which are compounded by negative shifts in their terms of trade and industrial output that, subsequently, attract declining shares of new global investment.

Central to these changes are rises in electricity production costs. As shown in Figure 2, this rise is highest for China and least for Japan and the EU. Low energy price inflation in Japan and the EU is consistent with both regions' comparatively low dependency on conventional fossil fuels. Both use nuclear power extensively, along with renewables, and the EU's carbon trading scheme has played some role in shifting energy use away from fuels (Sovacool 2008). This combination of factors causes comparatively modest European fossil fuel use in the initial database. ${ }^{20}$ Cost rises in energy-intensive industries on the imposition of the tax are

\footnotetext{
${ }^{19}$ This proves to be consistent with Nordhaus' (1996) finding as regards energy efficiency in Japan and Europe.

${ }^{20}$ Electricity sector spending is based on an input-output database. Refer to the Appendix for details.
} 
therefore comparatively small so that investment is attracted from high-cost regions and industrial structural changes, yielding net gains in aggregate output.

As the second largest of the emerging economies represented, the implementation of the tax causes the same adverse effects in Indonesia as for China. Real GDP contraction reflects that Indonesia suffers a decline in output that is almost as large as China, but which is more sustained..$^{21}$ Its dependence on exports of coal and other commodities, along with the substantial rises in electricity, cause a contraction in its share of global investment that reduces its current account deficit and its trade surplus in the short run and, beyond that, its growth performance. Its manufacturing and energy-intensive industries expand nonetheless, suggesting a domestic efficiency gain from the carbon tax.

In the short run, the allocation of global saving to investment shifts from newly high-cost regions like China toward lower-cost regions like Japan and the EU. The realized rate of return on physical capital declines in all regions, yet by least in Japan and the EU. As illustrated in Figures 3 and 4, relative to the baseline there is stronger growth in both domestic and foreign investment in Japan and the EU. By contrast, Chinese investment moderates, rising again subsequently with positive net effect by 2040 , in response to comparative growth in Chinese productivity and energy efficiency. This resurgence is not in evidence for Indonesia, and for other comparatively high-cost countries.

The income earned from the ownership of foreign assets is important in determining regional per capita incomes. As shown in Figure 5, for the EU, the gains in GDP relative to the baseline are associated with gains in real per capita income, some of which stems from abroad. For Japan, dependence on income generated in foreign regions that have slower growth causes real per capita income growth to be slower than output growth. For other regions, real per capita income levels fall short of the baseline. In China's case, the shortfall is greatest in the medium term by 2.5 per cent, and unlike its real output, there is no later resurgence. This is due, in part, to the resurgence in foreign investment in China, so the income from the new capital is repatriated out of China. Indonesia's real income per capita also falls short of the baseline levels, but by just a per cent, about the same rate as for other ASEAN Countries.

\footnotetext{
${ }^{21}$ Deviations in export growth are summarised in the Figure 6 for all regions represented in the model.
} 


\section{Estimating Benefits from Climate Change Mitigation}

It is impossible to evaluate the strategic interaction between regions over mitigation policies without consideration of the benefits that might be expected from the associated levels of climate stabilization. Notwithstanding a large literature devoted to such benefits, the results have considerably greater variance than the more readily modeled economic costs of mitigation. One of the reasons for this is that the benefits are public - non-rival and nonexcludable. Another is that they rely on at least three research links, each of which carries uncertainty, namely the link between fossil fuel burning and atmospheric carbon, that between atmospheric carbon and temperature change and that between temperatures change and economic welfare. Here we rely on a survey of the literature that covers these links and a meta-analysis to quantify them. In the subsection to follow, we use what is known about these links to establish the link between carbon emissions and the climate-related impacts on global GDP. In the next subsection, we investigate divergences in these impacts across regions.

\subsection{Emissions, Climate and Global GDP Effects}

Here we link projected total carbon emissions (in Gigatonnes, or GT) to average global temperature (in ${ }^{\circ}$ Celsius) via the atmospheric concentration of greenhouse gas (parts per million, or ppm). In particular, we link the projected level of total carbon emissions to average surface temperature using the 2000-2100 global temperature scenarios of the Intergovernmental Panel on Climate Change (IPCC). First, each carbon taxation scenario from our model yields a separate simulated trajectory for carbon emissions. The IPCC temperature estimates are based on GHG Emission $\left(\mathrm{CO}_{2}\right.$ combined with other greenhouse gases, including Methane, $\mathrm{CFC}$ and Nitrous Oxide). Since the relative contribution of $\mathrm{CO}_{2}$ is about 80 per cent (Nordhaus 1991), here we neglect the contributions of other greenhouse gases. Second, the associated rises in average global surface temperature are taken from IPCC scenario ranges, which are projected through 2090 from the year 2000 with a very wide error band. ${ }^{22}$ For this reason, we adopt IPCC terminology and construct three different temperature scenarios: "low", "best" and "high". Total emission and temperature estimates under these three IPCC scenarios are illustrated in Figure 7.

Next, we investigate the global welfare impacts of changes in average surface temperature. Based on the survey by Tol (2009), 15 studies are included in our meta-analysis of the

\footnotetext{
${ }^{22}$ IPCC temperature scenarios are detailed in the Table 1.
} 
economic welfare impacts of warmer temperatures. ${ }^{23}$ These include enumerative studies based on natural experiments and statistical studies. In the enumerative approach, the welfare estimates are extrapolated from individual locations to the global scale and from the immediate past to the distant future. The statistical studies rely on uncontrolled experiments and measured differences across regions in climate and income. Despite the difference in analytical approach, these studies tend to agree that a rise in the average surface temperature by a single degree Celsius would actually benefit the economy on average. Rises above two degrees are injurious, however. Figure 8 illustrates the fitted relationship between the welfare impact (average global GDP loss) and the corresponding global average surface temperature rise, based on these studies.

The final step in estimating the global mitigation benefit involves calculating the welfare impacts of changes in global emissions, for each of the three IPCC scenarios. This is done by combining the fitted polynomial functions illustrated in Figures 7 and 8. The global welfare reduction per gigatonne of emissions is derived as shown in Figure 9. The high variance of IPCC temperature scenarios results in considerable divergence in welfare reduction estimates. The low-temperature scenario embodies the least economic risk. For global emissions that grow to 90 GT by 2050, there would be no economic loss under this scenario, whereas the best scenario would yield a decline of 10 per cent and the high more than 30 per cent. By comparison, current global emissions are around 37.2 GT. In the global uniform carbon taxation projection, discussed in the previous sub-section, it is shown that carbon emissions would be reduced by 36 GT. From Figure 10 this would confer a gain in 2050 global GDP of between eight and 45 per cent.

\subsection{Causal Factors Affecting Regional Divergences in GDP Effects}

There is considerable evidence that warming will not affect all regions equally. Climate change impacts depend on variations in temperature that depend on geographical location, altitude, geology, and micro-climate. Here we account for these variations. To quantify different climate impacts for each county identified in our study, we draw on the integrated assessment study of Roson and Sartori (2015) of six climate impacts based on meta-analysis sourced in the scientific and economic literature. Our focus is on four climate indicators: sea

${ }^{23}$ Refer to Table 2 for studies on temperature and welfare impacts. 
level rise (SLR), agricultural output, impacts of heat on labour productivity and the human health effects of climate. ${ }^{24}$

There is near-consensus that increases in global temperature raise sea level. ${ }^{25}$ Regional effects differ depending on the composition of shorelines, the total length of the coast and the geographic distribution of economic activity. Rason and Sartori calculate the SLR impacts as the percentage loss due to the retention of productive land endowment. They use the DIVA model of Arnell et al. (2013) to estimate the percentage change in coastal wetland loss, erodible coast and the fraction of total coastline based agriculture, using the UNEP Agriculture Database. The results suggest considerable regional variation in productive land endowment loss that is particularly large small islands states, Central America and Asia.

Climate effects on agricultural productivity are comparatively well understood. Substantial literature suggests that higher concentrations of $\mathrm{CO}_{2}$ change the regional pattern of precipitation and that this redistributes productive cultivation. The estimates by Roson and Satori (2015) build on their earlier work (2010), focussing on maize, wheat, and rice. They distinguish each country's latitude and agronomic adaptation, their results suggesting that a one-degree increase in global surface temperature might lead to a fall in cereal production of between two and four per cent. This conclusion accords with the findings by Schlenker and Roberts (2009). The most modest impacts turn out to be at the highest latitudes, particularly in Europe and North America.

As to labour productivity more generally, it is the change in the Wet Bulb Globe Temperature (WBGT) per degree Celsius that appears to diminish effective working hours. Kjellstrom (2009) assumed there is a minimum threshold above which rising temperatures deter labour productivity in agriculture, manufacturing, and services. These results were then generalised by Roson and Satori (2015), who find that agricultural labour productivity is reduced most by temperature rise and that the effect is largest in the humid tropics. But it is not only heat and humidity that affects labour productivity. Vector-borne heat-related diseases are also more destructive the higher the temperature climbs. Our estimation of this effect relies on the earlier work of Bosello et al. (2006) and the 2014 IPCC Assessment Report.

\footnotetext{
${ }^{24}$ Here we omit climate impacts on tourism and household energy demand which require feedbacks between mitigation benefits and our modeling that are not captured.

${ }^{25}$ Despite disagreement as to the equilibrium sea level and its links with GHG concentration, the literature from paleo-climatic records suggests that sea level is higher than centuries ago. See Hensen et all. (2016).
} 


\subsection{Region Specific Climate Benefit Factors}

We estimate regional to global average climate benefit ratios in two steps. In the first, the perregion net effects on GDP are estimated for all the causal factors outlined in the previous section. Second, for each region the four GDP effects are multiplied by their respective GDP shares and added. More specifically, region-wide effects of agricultural output changes are approximated by multiplying by agriculture's value-added share, labour productivity effects due to heat stress and disease incidence are estimated via the product of the sectoral productivity effect and the ratio of sectoral labor income to total GDP. Finally, for SLR, estimated changes of land productivity are multiplied by the share of land rent in total GDP. The addition of these causal effects yields the region-specific GDP incidence per degree increase in the average surface temperature. These results are summarised in Appendix Table A8.

The second step is to estimate the regional benefit ratio as the ratio of the regional to the average global welfare effect, measured as the percentage change in GDP. If the global benefit (per cent change in global GDP) per degree reduction in average surface temperature is $\bar{B}_{W}$ and the corresponding regional benefit is $B_{i}$, the ratio of regional to global benefit is $B_{i} / \bar{B}_{W}$, which must be normalised to satisfy:

$$
\bar{B}_{W}=\sum_{i=1}^{n}\left(\frac{Y_{i}}{\sum_{j} Y_{j}}\right) B_{i} \text { or } \sum_{i=1}^{n}\left(\frac{Y_{i}}{\sum_{j} Y_{j}}\right)\left(\frac{B_{i}}{\bar{B}_{W}}\right)=1
$$

To be consistent with the three different IPCC' temperature scenarios introduced in section 4.1, the regional benefit ratio is calculated for temperature rises of from 1 to 5 degrees Celsius. An average is then taken across five sets of estimates, as indicated in Table 3.

\section{Strategic Interaction Analysis}

The payoffs for each region are based on comparisons of the benefits from mitigation at the regional level, derived from the previous section, with the associated mitigation costs, calculated using the model as per Section 3. Net global and regional gains are calculated for each year from 2015 to 2050 . The global scale of these gains depends, however, on the mix of regions participating. Moreover, the results arise in triplicate given the three IPCC temperature scenarios discussed previously. The costs (positive or negative) facing regions that do not participate stem only from changes in the paths of their terms of trade, real 
exchange rate and investment that are due to the implementation of the tax by other regions. These vary depending on the mix of regions participating. For regions that do participate, the effects of these changes are added to the direct effects of their implementation of the tax. These mitigation costs are then deduced from gains due to moderated temperature changes at both the global and regional levels.

Our starting hypothesis is that these payoffs are structured to resemble a coordination game, where there are multiple Nash equilibria and the mix of policies leaves the world in an inferior equilibrium from which no region would gain by moving unilaterally. All, or at least a "critical mass", of countries and regions must act together. Under these conditions, Schelling (1980) identified "focal points" as means to help resolve the coordination problem, an idea which favours the constant-rate carbon tax as a device for simplifying the interaction choice (Avi-Yonah \& Uhlman 2012).

Here the payoffs are constructed as discounted present values, constructed over the period 2016 to 2050, of net welfare effects in 2015. The global paths on which these are based are indicated in Figure 9. The net welfare effect for each year is derived as 2015 dollar values by multiplying the net percentage change with the projected GDP for each region by its corresponding level and discounting them at the 2017 US 10 year Treasury bond yield of 2.35 per cent. ${ }^{26}$

Significant emission contributions from China, the US, and the EU distinguish these large, regions from others. For this reason, the first scenario considered focusses on these three regions. Other regions are assumed to defect (not to participate in carbon taxation and hence abatement). Since there are more than two players, the normal form game requires more than four combinations. The combination of decision options follows Pascal's triangle, where the number, $k$, of combinations of $n$ elements is the sum of the $n$-th row of the binomial coefficients. ${ }^{27}$

\footnotetext{
${ }^{26}$ The discount rate of 2.35 percent is considered to be high compared to the less than one percent chosen for the Stern Review (Stern 2006). A tendency toward a declining social discount rate is proposed by Weitzman (2001), Gollier and Weitzman (2010), Gollier (2012) and Arrow et al. (2014). We follow Gollier and Zeckhauser (2005) and Heal (2017), who see difficulties in arriving at a Pareto efficient path given the nature and extent of climate change externalities.

${ }^{27}$ The number, $k$, of combinations given set ,S, with $n$ elements is denoted as $\mathrm{C}_{k}^{n}$. Alternatively, $\left(\begin{array}{l}n \\ k\end{array}\right)$ is read as $n$ chose $k$.
} 


$$
\sum_{0 \leq k \leq n} c_{k}^{n}=\sum_{0 \leq k \leq n}\left(\begin{array}{l}
n \\
k
\end{array}\right)=2^{n}
$$

And the number of subsets in each combination is obtained by calculating the whole number between 1 and $n$, where $n, k \in R$, or:

$$
\sum_{0 \leq k \leq n}\left(\begin{array}{l}
n \\
k
\end{array}\right)=\frac{n !}{k !(n-k) !}
$$

It follows that the game between the three largest players (the US, China and Europe), each facing just the two options (participate in the carbon tax program or defect), has eight strategic combinations, which comprise one zero-participation subset, three subsets where one country participates, three subsets where two countries participate and one subset in which three countries participate. The static, normal form game analysis for this case is illustrated in Figure 10.

\subsection{Strategic Game Analysis: The Big Three (China, USA, EU)}

This analysis is undertaken for each of the three IPCC temperature scenarios. We take them in turn.

\section{The IPCC "low temperature" case:}

The payoffs, in this case, prove inconsistent with the hypothesized coordination game. A single Nash Equilibrium appears and it combines defection by all three regions. In this case, the global welfare losses due to average surface temperature changes are very modest and so there is a disincentive to participate for all regions. Further investigation (Table 4) reveals, even if all three regions were to participate, estimated global emissions would be reduced to 87.35 GT in the year 2050, suggesting a welfare gain of only 0.16 per cent of global GDP. By comparison, China's participation cost would be 2.76 per cent of its projected GDP. The calculus is similar for the US and the EU.

The dominant strategy to defect yields the best economic outcome, at least for China and the US. The option of all participating offers no superior outcome. With defection, China avoids a present value loss amounting to three trillion USD while the US enjoys a slightly higher benefit. By contrast, despite the fact that the EU's best individual strategy is to defect, it would be better off if all three choose mitigation. 
The "best” IPCC temperature scenario:

In this case, while a coordination game is not evident, it is distinctive that the US and China now have unilateral incentives to participate. The Nash equilibrium has the US and China implementing mitigation policy while Europe is better off free riding. Decisions to defect or participate are influenced by China. Once China participates, the EU's best strategy is to defect.

The IPCC “high” temperature scenario:

The mitigation gains, in present value terms, are significant in this case. All three regions choose to participate. In this most serious case the benefit far exceeds the US mitigation cost and so it faces a strong incentive to participate and hence to impose the carbon tax. The China and EU contributions are equally substantial and so they face similar incentives.

\subsection{Strategic Game Analysis: Five Countries}

In the three region analysis and the "best" and "high" temperature cases, each region's contribution to global emission abatement plays a critical role in determining its incentive to participate. It is therefore likely that strategic incentives differ for regions with smaller emissions. Here we add to the analysis two smaller regions that, nonetheless, generate high emissions per capita, namely Indonesia and Australia. With five regions the game has 32 combinations $\left(2^{5}\right)$, including the subsets in which either no regions or all regions participate in implementing the tax. There are also five subsets pairing one region with four and ten pairing two and three. The payoff matrices for this multi-player game are summarized and illustrated in Figure 11.

The IPCC “low temperature” case:

Given that the large regions all defect in the three player game it is not surprising that no regions participate in this variant. All face dominant non-participation strategies. For the two smaller regions the cost of mitigation is high compared with the benefits that would accrue from it. Implementing unilaterally would, for Australia and Indonesia, cause the present value of GDP losses of 0.28 and 0.26 Trillion USD respectively, yielding no abatement action. This dominant strategy, for all to defect, is also not consistent with a prisoner's dilemma, in that participation by all does not confer net benefits for all regions. 


\section{The IPCC "best" temperature scenario:}

As before there is no coordination game. Except for the US and China, all regions choose to free ride. The costs the other regions face in implementing the tax are set against comparatively small increments to shared global welfare from the resulting mitigation. By contrast with the "low" scenario, and consistent with the earlier unilateral analysis, the US and China enjoy unilateral gains from abatement even when, because other regions defect, no other region contributes to that abatement. This finding emphasizes the central role of these big two emitters in global climate change abatement.

\section{The IPCC "high" temperature scenario:}

This yields a more striking result. The two smaller economies that consider investment in abatement, Australia, and Indonesia, still choose to free ride. Even with larger benefits from abatement, the implementation cost is too high to justify participation by these small emitters. The accumulated present value of their net impact is negative if both commit to the tax.

Despite universal participation does yield net benefits at the global level, the free riding incentives are shown to prevent participation by all regions even in the "high" scenario, where global net gains arise. If the free rider losses are smaller than the collective welfare or revenue gains by the larger regions that would participate, then this excess gain could feasibly finance side payments to induce universal participation. The following subsection will assess the potential affordability of such side payments, as a means to overcome this free rider problem.

\subsection{Free Riding and the Potential Affordability of Side Payments}

We have seen that the US and China consistently derive net gains from bearing the cost of abatement in both the "best" and the "high" IPCC temperature scenarios, while the EU is a net gainer from unilateral implementation only in the "high" scenario. In both these scenarios, the three largest economies taken together (the "big three") would implement carbon taxation irrespective of the behavior of other regions. Yet this raises difficult politics. It is easier to advocate the implementation of a tax that is costly in the short term if other regions are committed to it. Free riding therefore remains a political stumbling block. Moreover, if the rest of the world were also to implement the tax the global gains from mitigation would be substantially increased and the implementation cost would be smaller for the big three. 
It is therefore important to consider whether side payments to all the smaller economies are feasible. The net benefit from mitigation that is enjoyed by the big three is enhanced if mitigation policy is implemented by all other regions. If the quantum of this enhancement exceeds the total additional cost borne by the other regions, it follows that there exist affordable transfer payments that would improve welfare in the big three and globally. ${ }^{28}$

The most practical way to assess this would be based on receipts from carbon taxation, since these would be readily available for redistribution. In our model, however, revenue from carbon taxation raises domestic government expenditure and its diversion abroad would create unaccounted-for, indirect national losses in implementing regions. We, therefore, consider affordability from the accumulated present value of net future benefits. If net benefits from abatement are sufficient to compensate for the losses in other regions then side payments are affordable, even though this would require considerable intertemporal redistribution in the big three.

Our first step is to measure the present value of the stream of global welfare improvements, relative to a no-abatement case, in each carbon tax implementation (Table 5). In the second, this number is adjusted by each region's benefit share, followed by the mitigation cost the and corresponding present value of their projected GDP to get the net welfare effect of carbon mitigation, both in regions that implement the tax and those that do not. We calculate the present value of the stream of extra benefits gained by the big three carbon taxing emitters (China, the US, and the EU) when all the otherwise free-riding regions also implement the tax. This extra benefit arises both from reduced global surface temperature and from terms of trade changes due to taxation in the other regions. We then estimate the present value of actual net losses that would be incurred by the previously free-riding regions, due to their switch to the implementation of the abatement strategy.

Should the present value of the extra gains by the top three exceed the present value of aggregate incremental losses by these regions, there is room for side payments. For parsimony, we limit the side payment analysis to only the "best" temperature scenario, where in that case, and the "high" temperature scenario, the free riding and the prisoner's dilemma structure are clearest. Table 6 summarizes the total extra benefit of the big three emitters

\footnotetext{
${ }^{28}$ This approach is consistent with the Carraro and Siniscalco (1993) definition of stable transfer payments. To achieve a stable coalition, where there are no incentives to free ride, the total transfers should be lower than the gain the committed member would obtain from the expanding coalition, But must be larger on net than the potential member's net loss associated with joining other regions in adopting abatement
} 
from the global implementation and the aggregated loss of other regions due to their switching from free riding to implementation. The present value of the additional net welfare benefits to China, the US, and the EU, which arises from the implementation of the tax by all other regions, is estimated roughly at 27 Trillion USD. This would be sufficient to compensate for a present-value incremental net loss of 15 T USD in the other regions.

If this analysis is implemented on an annual basis, rather than in present value terms, there are years in which the capacity for compensation is sufficient and years in which it is too small. Sadly it is during the early years that the compensation would be inadequate. Indeed, the extra benefit gained by the big three would not be sufficient to compensate the total loss carried by other regions, at least until the year 2035. As illustrated in Figure 12, the total loss due to switching from free riding to the implementation of the tax in the smaller regions is stable throughout the simulation period at something under 0.5 trillion USD per year. For the big three, however, the net gains are negative throughout the first two decades. Indeed, as Figure 13 shows, within the first two decades, the big three would experience net negative benefits from carbon abatement. The turning point would be two decades after tax is implemented, substantial for China and the US yet very modest for Europe. While this is consistent with our finding that both the US and China are net gainers from unilateral tax implementation, the task is made politically difficult due to the need to wait almost an entire generation for the net gains to begin to flow.

\subsection{Sensitivity Analysis: Discount Rate}

There are many points in this analysis that have required facilitating assumptions. ${ }^{29} \mathrm{We}$ regard the rate at which future benefits and costs are discounted to be the strongest of these and so it is important that the associated sensitivity of results be explored. Here we consider the 10 year US Treasury bond rate to be at the low end of a possible range, given that abatement policies are to be implemented in economic environments where the opportunity cost of capital depends on commercial financing rates, and particularly those in the energy and electricity sectors. We therefore consider two additional discount rates: five per cent captures the cost of equity in commercial activity in open economies generally. We also

\footnotetext{
${ }^{29}$ Beyond the structural assumptions embodied in our modelling of costs, there is our omission of risk preferences from the analysis and our assumption that the regional distribution of economic effects does not depend on which regions implement abatement policy but only on the collective effect on global emissions. These are clearly matters for further work.
} 
consider a rate of seven point two per cent to represent cost of capital in energy and energy intensive industries. ${ }^{30}$

With these different discount rates, the game theoretic results from all scenarios confirm the previous findings, for almost all regions. Variations are, nonetheless, of particular interest. In the "best" temperature scenario, we find that the choices of the USA and China are sensitive to the discount rate. At the five per cent rate, the US participation strategy becomes less dominant, yet the equilibrium unilateral participation alongside China.

At seven point two per cent, China and the US are highly interactive. Two equilibria emerge in which either China or the US participates, but they do not do so together. The best reaction of the US is now to defect if China commits and to participate if China commits to defect. China's optimal reactions are the converse highlighting the strong incentives for members of the big three to free ride once one other large emitter decides to commit.

As to the affordability of side payments, under the "best" temperature scenario, at the higher discount rates, the big three would not be able to afford compensation sufficient to induce universal implementation. In the "high" temperature scenario, however, the total discounted value of the now augmented benefits to the big three would still be sufficient to finance the necessary transfers, albeit with considerable intertemporal wealth transfers domestically.

\section{Conclusion}

The ineffectiveness of the Kyoto Protocol and the constraints facing the success of the Paris Accord arise from hesitation among nations in the face of costly mitigation actions, combined with incentives for smaller regions to free ride on the commitments of larger ones. Because the uniform carbon taxation scheme offers a simple and internationally transparent negotiation target on the one hand and a comparatively efficient economic policy measure on the other, we adopt it as a policy model to explore and quantify these strategic issues.

The effects of varying numbers and sizes of regions that might commit to such a tax are considered by conducting simulations of a global economic model and combining these with the results from a meta-study of the temperature and economic welfare impacts of alternative levels of global carbon emission. Three IPCC temperature rise cases are considered: "low", "best" and "high". These yield quite different economic gains from moderating the rise in

\footnotetext{
${ }^{30}$ For consideration of the discount rate as the cost of capital see Nordhaus (2007) for an evaluation of the cost capital facing US industries. See: http://www.stern.nyu.edu/ adamodar/New_Home_Page/data.html.
} 
average global surface temperature. In the "best" case, the results suggest that the absence of further carbon mitigation will see the average surface temperature rise by four degrees Celsius, bringing with it a loss to the global economy of 15 per cent of its GDP. In the IPCC "high" temperature case this impact is almost doubled. More modest results emerge in the "low" temperature case. When mitigation is added via carbon taxation at 20 USD per tonne, five key conclusions emerge.

First, the more widespread is the implementation of the tax the more the global terms of trade is shifted in favour of just a few comparatively energy-efficient regions, including the EU and Japan. Gains to these regions stem both from the abatement and hence lower temperatures as well as from these terms of trade improvements. Second, in the "best" and "high" IPCC temperature scenarios, in present value terms the US and China would derive positive net economic gains from their unilateral implementation of the tax, irrespective of the behaviour of other regions.

Third, in the "best" scenario, the large carbon-emitting regions, namely the US, the EU, and China, have sufficient individual effects on the global climate that the gains each would derive from their joint implementation of the tax, and hence their unilateral effects on the global surface temperature, exceed their collective economic costs of implementing it. Together, they face a purely economic incentive to implement the carbon tax that does not depend on whether other regions choose to do so. This finding contradicts the analysis using the DICE-Coalition model by Nordhaus (2015), with their pessimistic result ruling out a coalition without penalties. It does, however, confirm the "small paradox" theory of Barrett (1994; 2003). It also highlights the crucial role of China, rather than Japan, in global climate policy.

Fourth, in the "best" IPCC temperature scenario, were they able to coordinate, China, the US and the EU would choose to implement the tax collectively. The question then arises as to whether the additional gains they would derive (via lower temperatures and further terms of trade changes) were the remaining regions also to implement the tax would be sufficient for them to afford side payments large enough to induce the other regions to do so. Our results show that, so long as future benefits and costs are discounted at the 2017 ten year Treasury bond yield, their additional gains are quite sufficient to finance such side payments. At higher rates of discount, only the IPCC "high" temperature scenario yields net gains to the big three that are large enough to compensate other regions for participation. Indeed, at these higher 
discount rates, strategic interaction between the US and China is heightened in the "best" temperature scenario, with only one facing unilateral net gains from implementation. When one commits to abatement policy the other will free ride.

Fifth, and finally, it is shown that carbon abatement policies will be politically difficult to implement by all countries, even the US and China, which are the only unilateral gainers under the "best" temperature scenario. This is because the annual net gains do not turn positive for at least two decades. This finding suggests pessimism about the potential for implementation in the "anchor" regions but, moreover, since no side payments would be affordable in the first two decades, the potential for wider coalition building also looks bleak. Nonetheless, even though net benefits are negative in the early decades, implementing regions would be generating considerable public revenue from the taxes and these could be a source of inducement through global redistributions. Yet, even this would require strong forward looking behaviour by governments.

\section{References}

Aldy, JE, Barrett, S \& Stavins, RN 2003, 'Thirteen plus one: a comparison of global climate policy architectures', Climate Policy, vol. 3, no. 4, pp. 373-397. Available from: http://www.tandfonline.com/doi/abs/10.1016/j.clipol.2003.09.004.

Aldy, JE \& Stavins, RN 2012, 'The promise and problems of pricing carbon: theory and experience', The Journal of Environment and Development, vol. 21, no. 2, pp 152180. Available from: http://jed.sagepub.com/content/early/2012/01/24/1070496512442508.full.pdf+html.

Arnell, NW, Lowe, JA, Brown, S, Gosling, SN, Gottschalk, P, Hinkel, J, Lloyd-Hughes, B, Nicholls, RJ, Osborn, TJ, Osborne, TM \& Rose, GA 2013, 'A global assessment of the effects of climate policy on the impacts of climate change', Nature Climate Change, vol. 3, no. 5, pp.512-519.

Arrow, KJ, Cropper, ML, Gollier, C, Groom, B, Heal, GM, Newell, RG, Nordhaus, WD, Pindyck, RS, Pizer, WA., Portney, PR \& Sterner, T 2014, 'Should governments use a declining discount rate in project analysis?', Review of Environmental Economics and Policy, vol. 8, no. 2, pp.145-163.

Avi-Yonah, RS \& Uhlmann, DM 2009, 'Combating global climate change: why a carbon tax is a better response to global warming than cap and trade', Stanford Environmental Law Journal, vol. 28, no. 3. 
Barrett, S 1994, 'Self-enforcing international environmental agreements', Oxford Economic Papers, pp. 878-894.

Barrett, S 2002, 'Consensus treaties', Journal of Institutional and Theoretical Economics, vol. 158 , no. 4 , pp. $529-547$.

Barrett, S 2003, 'Environment and statecraft: The strategy of environmental treaty-making: The strategy of environmental treaty-making', OUP Oxford.

Bolton, GE \& Ockenfels, A 2000, 'ERC: A theory of equity, reciprocity, and competition', The American Economic Review, vol. 90, no. 1, pp. 166-193. Available from: http://www.jstor.org/stable/117286.

Böhringer, C, Carbone, JC \& Rutherford, TF 2012, 'Unilateral climate policy design: Efficiency and equity implications of alternative instruments to reduce carbon leakage', Energy Economics, vol. 34, pp. S208-S217.

Böhringer, C, Carbone, JC \& Rutherford, TF 2016, 'The strategic value of carbon tariffs', American Economic Journal: Economic Policy, vol. 8, no. 1, pp. 28-51.

Böhringer, C, Rosendahl, KE \& Storrøsten, HB 2017, 'Robust policies to mitigate carbon leakage', Journal of Public Economics, vol. 149, pp. 35-46.

Bosello, F, Roson, R, \& Tol, RSJ 2006. 'Economy-wide estimates of the implications of climate change: human health', Ecological Economics, vol. 58, pp. 579-591.

Burniaux, JM \& Martins, JO 2012, 'Carbon leakages: a general equilibrium view', Economic Theory, vol. 49, no. 2, pp. 473-495.

Burniaux, JM \& Truong, TP 2002, GTAP-E: an energy-environmental version of the GTAP model, GTAP Technical Papers no. 16, Purdue University. Availiable from: https://www.gtap.agecon.purdue.edu/resources/download/1203.pdf.

Caparrós, A \& Péreau, JC 2017, 'Multilateral versus sequential negotiations over climate change', Oxford Economic Papers, vol. 69, no. 2, pp. 365-387.

Carraro, C \& Siniscalco, D 1993, 'Strategies for the international protection of the environment', Journal of Public Economics, vol.52, no. 3, pp. 309-328.

Carraro, C \& Siniscalco, D 1998, 'International Institutions and Environmental Policy: International environmental agreements: Incentives and political economy', European Economic Review, vol. 42, no 3-5, pp. 561-572. 
Clarke, H \& Waschik, R 2012, 'Australia's carbon pricing strategies in a global context', Economic Record, vol. 88, no. s1, pp. 22-37.

Cooper, RN, Cramton, P, Dion, S, Edenhofer, O, Gollier, C, Laurent, É, MacKay, DJC, Nordhaus, W, Ockenfels, A \& Stiglitz, J 2016, 'Why Paris did not solve the climate dilemma' in P Crampton, DJC MacKay, A OCkenfels \& S Stoft, (eds), Global Carbon Pricing, pp.1-6. MIT Press, Cambridge.

Cooper, RN 1998, 'Toward a real global warming treaty', Foreign Affairs, vol. 77, no. 2, pp. 66-79.

Cooper, RN 2001, The Kyoto Protocol: a flawed concept, FEEM Working Paper no.52.2001, Harvard University. Available from: https://papers.ssrn.com/sol3/Papers.cfm?abstract_id=278536.

Cooper, RN 2007, 'Alternatives to Kyoto: the case for a carbon tax', in JE Aldy \& RN Stavins, (eds), Architectures for agreement: Addressing global climate change in the post-Kyoto World, pp. 105-115. Cambridge University Press, Cambridge. Available from: http://dev.wcfia.harvard.edu/sites/default/files/Cooper_Alternatives.pdf.

Cramton, P, Ockenfels, A \& Stoft, S 2015, 'An international carbon-price commitment promotes cooperation', Economics of Energy and Environmental Policy, vol. 4, no. 2 , pp. 51-64.

DeCanio, SJ \& Fremstad, A 2013, ‘Game theory and climate diplomacy’, Ecological Economics, vol. 85, pp. 177-187.

Dimitrov, RS 2016, 'The paris agreement on climate change: behind closed doors', Global Environmental Politics, vol. 16, no. 3, pp. 1-11.

Ekins, P \& Speck, S 1999, 'Competitiveness and exemptions from environmental taxes in Europe', Environmental and Resource Economics, vol. 13, no. 4, pp. 369-396.

Falkner, R, Stephan, H \& Vogler, J 2010, 'International climate policy after Copenhagen: towards a 'building blocks' approach', Global Policy, vol. 1, no. 3, pp. 252-262.

Fehr, E \& Gächter, S 2000, 'Fairness and retaliation: the economics of reciprocity', The Journal of Economic Perspectives, vol. 14, no. 3, pp. 159-181.

Fouré, J, Bénassy-Quéré, A \& Fontagné, L 2010, The world economy in 2050: a tentative picture, CEPII Working Paper no. 2010-27, CEPII, Paris. Available from: http://cepii.fr/PDF_PUB/wp/2010/wp2010-27.pdf. 
Fouré, J, Bénassy-Quéré, A \& Fontagné, L 2013, 'Modelling the world economy at the 2050 horizon', Economics of Transition, vol. 21, no. 4, pp. 617-654. Available from: http://onlinelibrary.wiley.com/doi/10.1111/ecot.12023/full.

Gollier, C 2012, Pricing the Planet's Future: The Economics of Discounting in an Uncertain World, Princeton University Press, Princeton.

Gollier, C \& Weitzman, ML 2010, 'How should the distant future be discounted when discount rates are uncertain? ', Economics Letters, vol. 107, no. 3, pp. 350-353.

Golub, A 2013, Analysis of Climate Policies with GDyn-E, GTAP Technical Paper no. 32, Purdue University. Available from: https://www.gtap.agecon.purdue.edu/resources/download/6632.pdf.

Hanoch, G 1975, 'Production and demand models with direct or indirect implicit additivity', Econometrica: Journal of the Econometric Society, vol. 43, no. 3, pp. 395-419.

Hansen, J, Sato, M, Hearty, P, Ruedy, R, Kelley, M, Masson-Delmotte, V, Russell, G, Tselioudis, G, Cao, J, Rignot, E \& Velicogna, I 2016, 'Ice melt, sea level rise and superstorms: evidence from paleoclimate data, climate modeling, and modern observations that $2 \mathrm{C}$ global warming could be dangerous', Atmospheric Chemistry and Physics, vol. 16, no. 6, pp. 3761-3812.

Heal, G 2017, 'The economics of the climate', Journal of Economic Literature, vol. 55, no. 3, pp. 1046-63.

Hertel, TW (ed) 1998, Global trade analysis: modeling and applications, Cambridge University Press, Cambridge.

Hoel, M 1992, 'International environment conventions: the case of uniform reductions of emissions', Environmental and Resource Economics, vol. 2, no. 2, pp. 141-159.

Hovi, J, Sprinz, DF \& Bang, G 2010, 'Why the United States did not become a party to the Kyoto Protocol: German, Norwegian and US perspectives', European Journal of International Relations, vol. 18, no. 1, pp. 129-150.

Hovi, J, Sprinz, DF, Sælen, H \& Underdal, A 2017, 'The Club Approach: A Gateway to Effective Climate Co-operation?', British Journal of Political Science, pp.1-26.

Howard, N 1971, Paradoxes of rationality: games, metagames, and political behavior, MIT Press, Cambridge.

Ianchovichina, E \& Walmsley, TL (eds) 2012, Dynamic modeling and applications for global economic analysis, Cambridge University Press, Cambridge. 
IEA 2006, Energy Balances of non-OECD Countries 2006, OECD Publishing, Paris.

Available from: http://dx.doi.org/10.1787/energy_bal_non-oecd-2006-en-fr.

IEA 2006, Energy Balances of non-OECD Countries 2006, OECD Publishing, Paris.

Available from: http://dx.doi.org/10.1787/energy_bal_oecd-2006-en-fr.

IMF 2016, World Economic Outlook, IMF, Washington DC. Available from:

http://www.imf.org/external/pubs/ft/weo/2016/02/.

IPCC 2007, Climate Change 2007: Synthesis Report. Contribution of Working Groups I, II and III to the Fourth Assessment Report of the Intergovernmental Panel on Climate Change, IPCC, Geneva. Available from: https://www.ipcc.ch/pdf/assessmentreport/ar4/syr/ar4_syr_full_report.pdf.

IPCC 2014, Climate Change 2014: Synthesis Report. Contribution of Working Groups I, II and III to the Fifth Assessment Report of the Intergovernmental Panel on Climate Change, IPCC, Geneva. Available from: https://www.ipcc.ch/pdf/assessmentreport/ar5/syr/SYR_AR5_FINAL_full_wcover.pdf.

Kjellström, T, Kovats, RS, Lloyd, SJ, Holt, T \& Tol, RSJ, 2009. 'The direct impact of climate change on regional labor productivity', Archives of Environmental \& Occupational Health, vol. 64, no. 4, pp. 217-27.

Kraft-Todd, G, Yoeli, E, Bhanot, S \& Rand, D 2015, 'Promoting cooperation in the field', Current Opinion in Behavioral Sciences, vol. 3, pp. 96-101. Available from: http://www.sciencedirect.com/science/article/pii/S2352154615000406.

Leroy, SF 2005, Excess volatility, Working Paper University of California, Santa Barbara. Available from: https://www.researchgate.net/publication/268374855_Excess_Volatility.

Lee, HL 2008, The combustion-based CO2 emissions data for GTAP Version 7 Data Base, Center for Global for Global Trade Analysis, Purdue University. Available from: https://www.gtap.agecon.purdue.edu/resources/download/4470.pdf.

Madani, K 2013, 'Modeling international climate change negotiations more responsibly: Can highly simplified game theory models provide reliable policy insights?', Ecological Economics, vol. 90, pp. 68-76.

Mahapatra, SK \& Ratha, KC 2017, 'Paris climate accord: miles to go', Journal of International Development, vol. 29, no. 1, pp. 147-154. 
Martimort, D \& Sand-Zantman, W 2016, 'A mechanism design approach to climate-change agreements', Journal of the European Economic Association, vol. 14, no. 3, pp. 669718.

Narayanan, G \& Walmsley, T (eds) 2008, The GTAP 7 Data Base, Center for Global Trade Analysis, Purdue University. Available from: http://www.gtap.agecon.purdue.edu/databases/v7/v7_doco.asp

Nordhaus, WD 1991, 'To slow or not to slow: the economics of the greenhouse effect', The Economic Journal, vol. 101, no. 407, pp. 920-937. Available from: http://www.jstor.org/stable/2233864?seq=1\#page_scan_tab_contents.

Nordhaus, WD \& Yang, Z 1996, ‘A regional dynamic general-equilibrium model of alternative climate-change strategies'. The American Economic Review, pp. 741-765.

Nordhaus, WD \& Boyer, JG 1999, 'Requiem for Kyoto: an economic analysis of the Kyoto Protocol', The Energy Journal, pp. 93-130.

Nordhaus, WD \& Yang, Z 2006, 'Magnitude and direction of technological transfers for mitigating GHG emissions', Energy Economics, vol. 28, no. 5-6, pp. 730-741.

Nordhaus, WD 2007, 'A review of the Stern review on the economics of climate change', Journal of Economic Literature, vol. 45, no 3, pp. 686-702.

Nordhaus, WD 2007, 'To tax or not to tax: alternative approaches to slowing global warming', Review of Environmental Economics and policy, vol. 1, no. 1, pp. 26-44.

Nordhaus, WD 2010, 'Economic aspects of global warming in a post-Copenhagen environment', Proceedings of the National Academy of Sciences, vol. 107, no. 26, pp. 11721-11726.

Nordhaus, WD 2011, 'Estimates of the social cost of carbon: background and results from the RICE-2011 model', National Bureau of Economic Research Working Paper.

Nordhaus, WD 2013, 'Chapter 16 - Integrated Economic and Climate Modeling', in PB Dixon \& WD Jorgenson, (eds), Handbook of Computable General Equilibrium Modeling, vol. 1A, pp. 1069-1131. North-Holland, Oxford.

Nordhaus, WD 2014, 'Estimates of the social cost of carbon: concepts and results from the DICE-2013R model and alternative approaches', Journal of the Association of Environmental and Resource Economists, vol. 1, no. 1-2, pp. 273-312. 
Nordhaus, WD 2015, 'Climate clubs: Overcoming free-riding in international climate policy', American Economic Review, vol. 105, no. 4, pp. 1339-70.

Perdana, S, \& Tyers, R 2016, Unilateral Carbon Taxation in Indonesia: Ecomic Implications, Economic Discussion Paper, University of Western Australia.

Pittel, K \& Rübbelke, DT 2008, 'Climate policy and ancillary benefits: A survey and integration into the modelling of international negotiations on climate change', Ecological Economics, vol. 68, no. 1-2, pp. 210-220.

Rezai, A \& van der Ploeg, F 2014, Intergenerational inequality aversion, growth and the role of damages: Occam's rule for the global carbon tax, OxCarre Research Paper no.150, University of Oxford. Available from: https://www.economics.ox.ac.uk/materials/papers/13817/paper150.pdf.

Richstein, JC, Chappin, ÉJL \& de Vries, LJ 2015, 'The market (in-) stability reserve for EU carbon emission trading: why it might fail and how to improve it', Utilities Policy, vol. 35, pp. 1-18.

Roson, R \& Sartori, M 2016, Estimation of climate change damage functions for 140 regions in the GTAP9 database, Policy Research Working Paper no. WPS 7728, The World Bank, Washington D.C. Avaliable from: http://documents.worldbank.org/curated/en/175901467994702565/Estimation-ofclimate-change-damage-functions-for-140-regions-in-the-GTAP9-database

Sælen, H 2016, 'Side-payments: an effective instrument for building climate clubs?', International Environmental Agreements: Politics, Law and Economics, vol. 16, no. 6, pp. 909-932.

Schelling, TC 1980, The strategy of conflict, Harvard University Press, Cambridge.

Schlenker, W, \& Michael, JR 2009, 'Nonlinear temperature effects indicate severe damages to U.S. crop yields under climate change', Proceedings of the National Academy of Sciences, vol. 106, no. 37, pp. 15594-15598. http://www.pnas.org/content/106/37/15594.full.pdf.

Schmalensee, R 1998, 'Greenhouse policy architecture and institutions', in WD Nordhaus, (ed), Economics and Policy Issues in Climate Change, pp. 137-158. RFF Press, Washington D.C.

Selbirak, T 1994, 'Some concepts of non-myopic equilibria in games with finite strategy sets and their properties', Annals of Operations Research, vol. 51, no. 2, pp.73-82. 
Shiller, RJ 1981, 'Do stock prices move too much to be justified by subsequent changes in dividends?', American Economic Review, vol. 71, no. 3, pp.421-436.

Sovacool, BK 2008, 'Valuing the greenhouse gas emissions from nuclear power: a critical survey', Energy Policy, vol. 36, no. 8, pp. 2950-2963.

Stern, N 2006, The economics of climate change: the Stern review, Cambridge University Press, Cambridge.

Stewart, RB, Oppenheimer, M \& Rudyk, B 2013, 'A new strategy for global climate protection', Climatic Change, vol. 120, no.1-2, pp. 1-12.

Tol, RSJ 2009, 'The economic effects of climate change', The Journal of Economic Perspectives, vol. 23, no. 2, pp. 29-51. Available from: http://www.ingentaconnect.com/content/aea/jep/2009/00000023/00000002/art00003.

Victor, DG 2011. Global warming gridlock: creating more effective strategies for protecting the planet, Cambridge University Press, Cambridge.

McKibbin, WJ, \& Wilcoxen, PJ 2002, Climate Change Policy after Kyoto: A Blueprint for a Realistic Approach, Brooking Institution Press, Washington, D.C.

McKibbin, WJ, \& Wilcoxen, PJ 2002, 'The Role of Economics in Climate Change Policy', The Journal of Economic Perspectives, vol. 16, no. 2, pp. 107-129.

McKibbin, WJ, Morris, AC, \& Wilcoxen, PJ 2008, Expecting the Unexpected: Macroeconomic Volatility and Climate Policy, Discussion Paper no. 2008-16, Harvard Project on International Climate Agreements, Cambridge. Available from: https://www.belfercenter.org/sites/default/files/legacy/files/McKibbinWeb2.pdf.

Weitzman, ML 2001, 'Gamma discounting', American Economic Review, vol. 91, no. 1, pp. $260-71$.

Weitzman, ML 2013, 'Can Negotiating a Uniform Carbon Price Help to Internalize the Global Warming Externality?' Journal of the Association of Environmental and Resource Economists, vol. 1, no. 1/2, pp. 29-49. Available from: https://doi.org/10.1086/676039.

Weitzman, ML 2015, 'Internalizing the climate externality: Can a uniform price commitment help?', Economics of Energy \& Environmental Policy, vol. 4, no. 2, pp.37-50. 


\section{FIGURES}

Figure 1: Real GDP Growth Deviation (\% Change from The Baseline), Following the Carbon Tax.

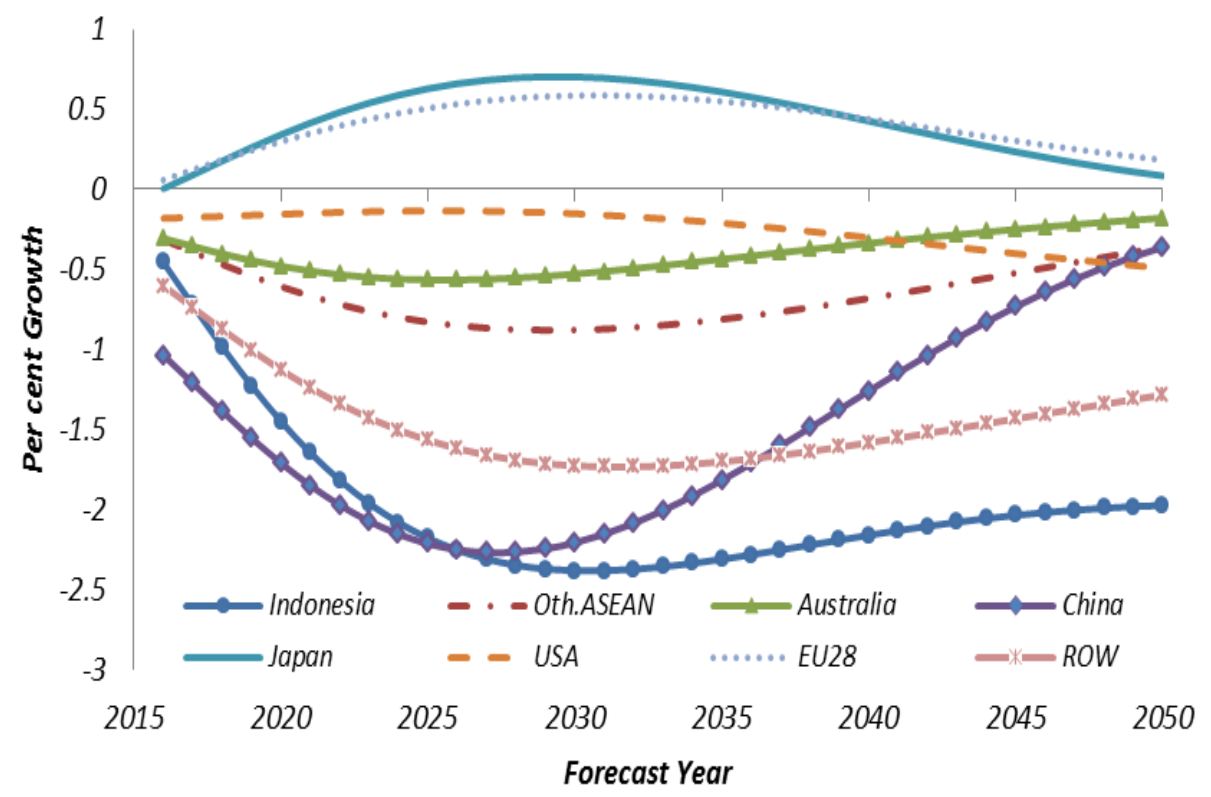

Source: Baseline Simulation of the model described in the text.

Figure 2: Price Deviation from Baseline: Secondary Industries (\% Change), Following Carbon Tax.

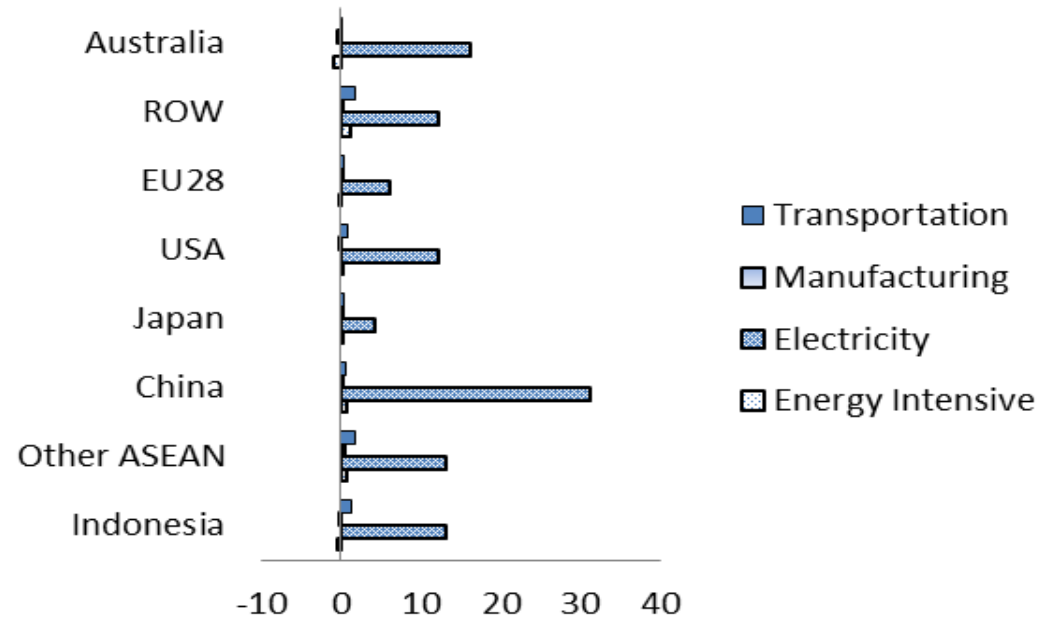

Source: Baseline Simulation of the model described in the text 
Figure 3: Domestic Purchase of Local Equity following the Carbon Tax: (\% Change)

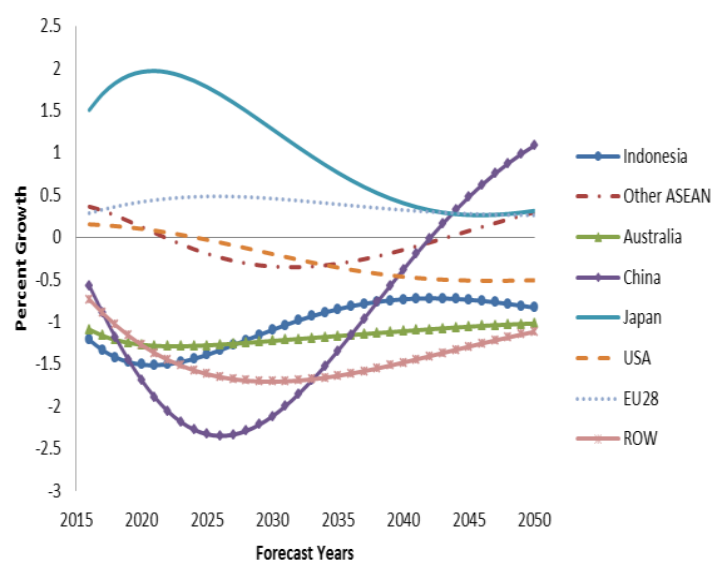

Figure 5: Real per Capita Income Growth Deviation (\% Change from Baseline)

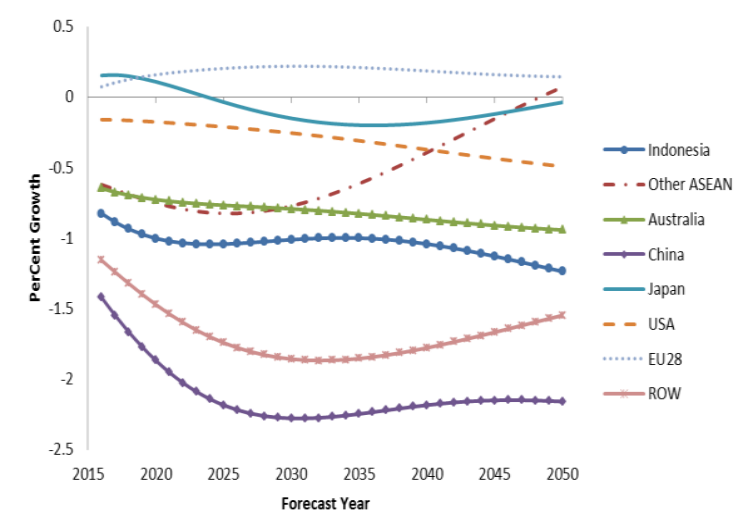

Figure 4 : Foreign Investment Growth (Local Equity Purchase by Foreign Investors)

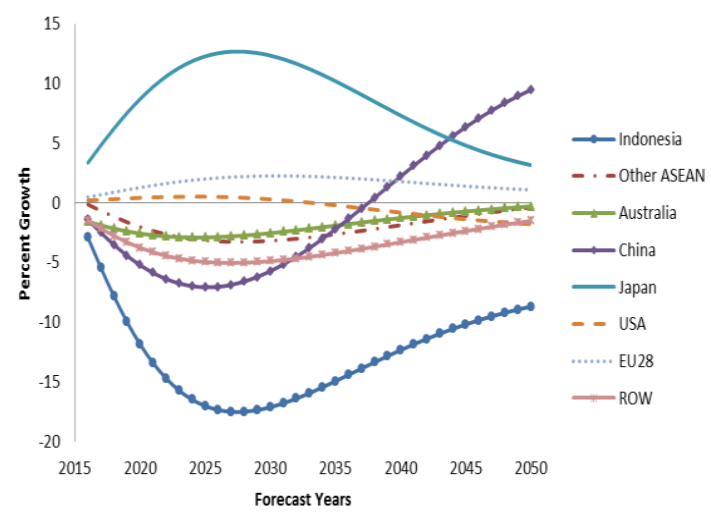

Source: Baseline Simulation of the model described in the text.

Figure 6: Projected Deviation Export Growth 2016-2050 due to Carbon Tax (\% Change from Baseline)

Aggregate Export Growth Deviation: Fossil Fuels

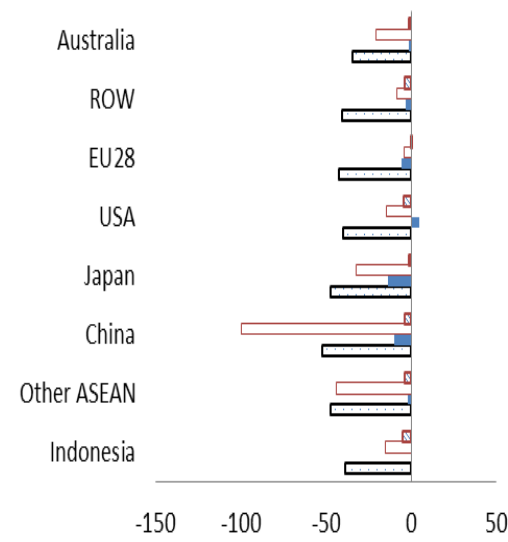

Output Growth Deviation: Secondary Industries

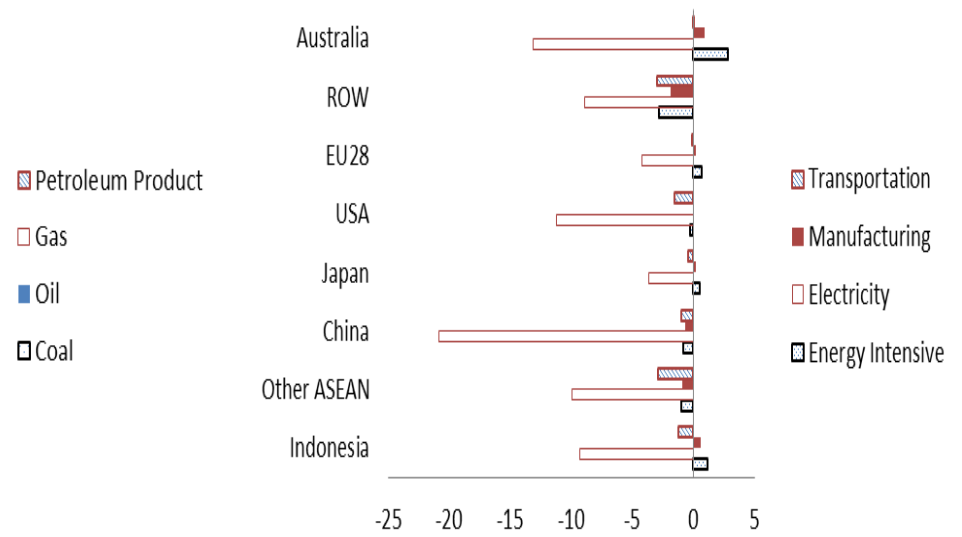

Source: Baseline Simulation of the model described in the text. 
Figure 7: Emission and Global Temperature Change from year 2015 (IPCC Scenarios)

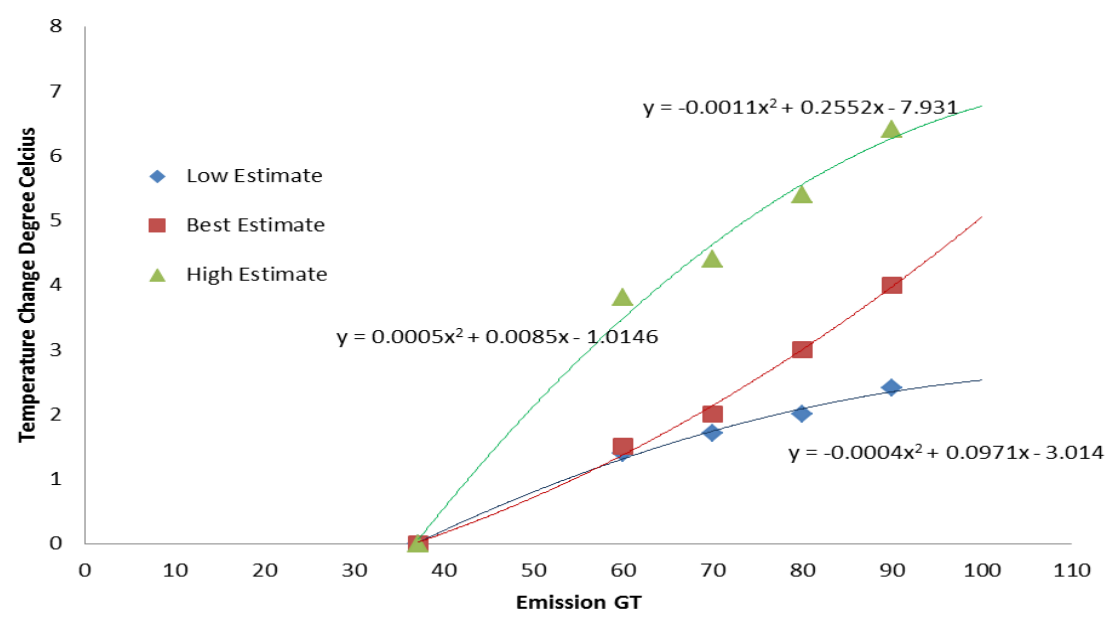

Source: IPCC modified / fitted (IPCC 2007: Synthesis Report)

Figure 8: Estimated Welfare Impacts for Different Temperature Changes

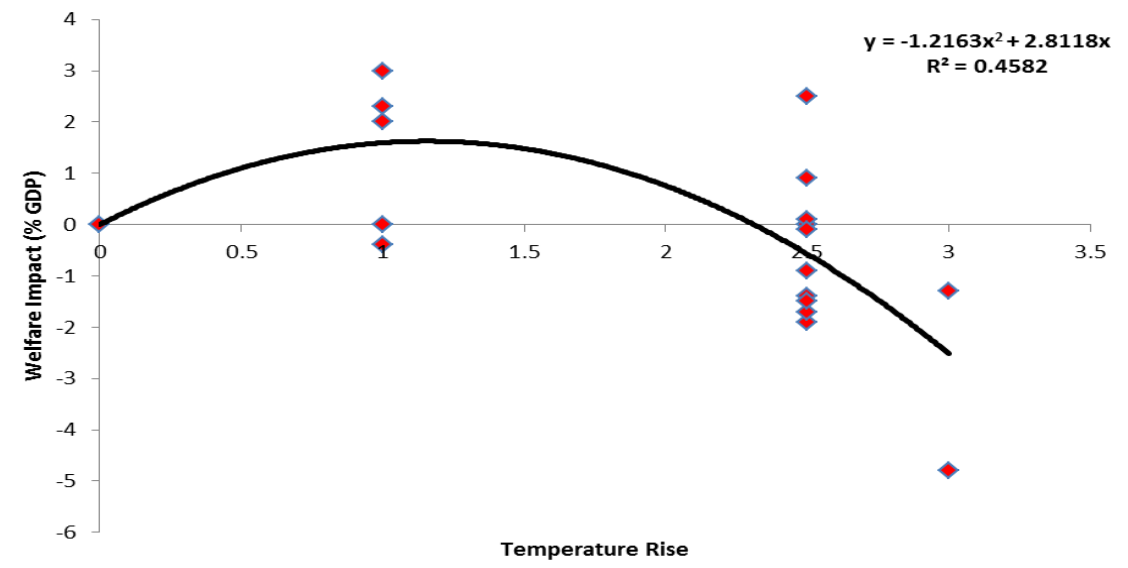

Source: Based on Figures attained by Tol (2009).

Figure 9: Relationship between Global Emissions and Global Economic Welfare (GDP)

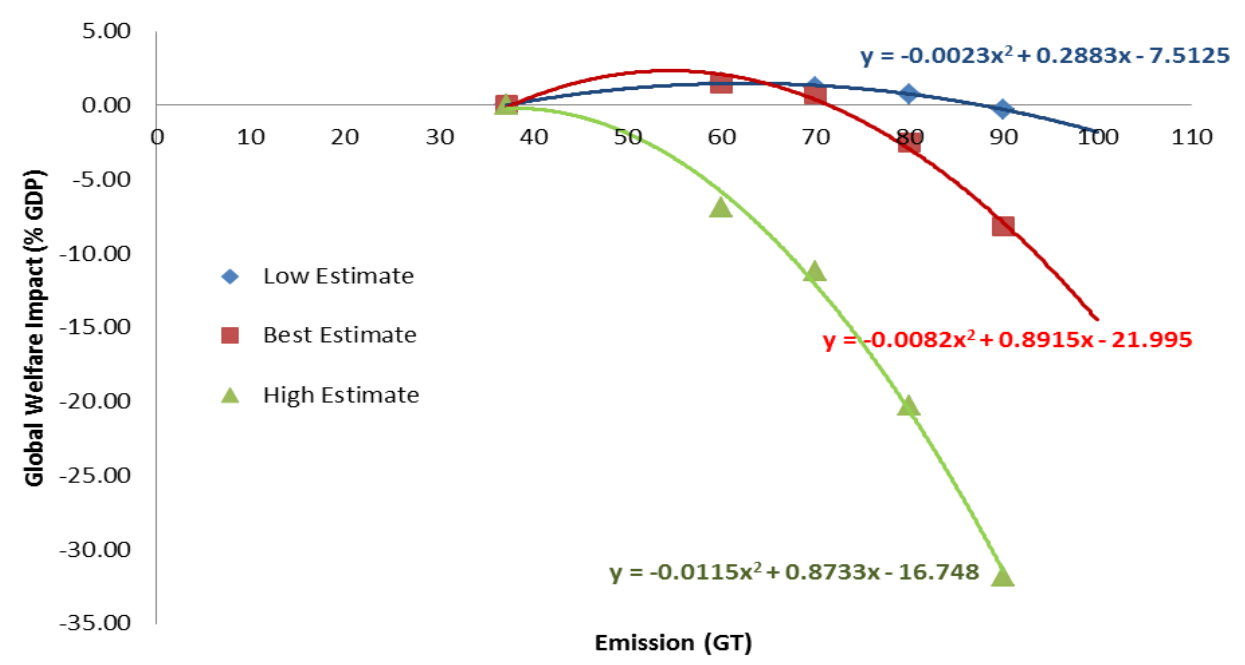

Source: Estimation as described in the text. 
Figure 10: Normal Form Static Games on Present Values for Three Countries (US, China, EU)

LOW Scenario (in Trillion USD)

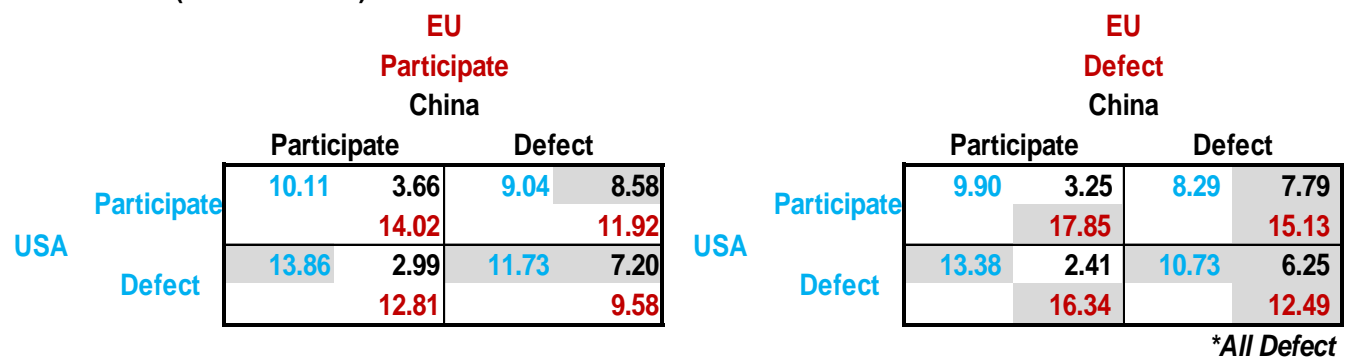

BEST Scenario (in Trillion USD)
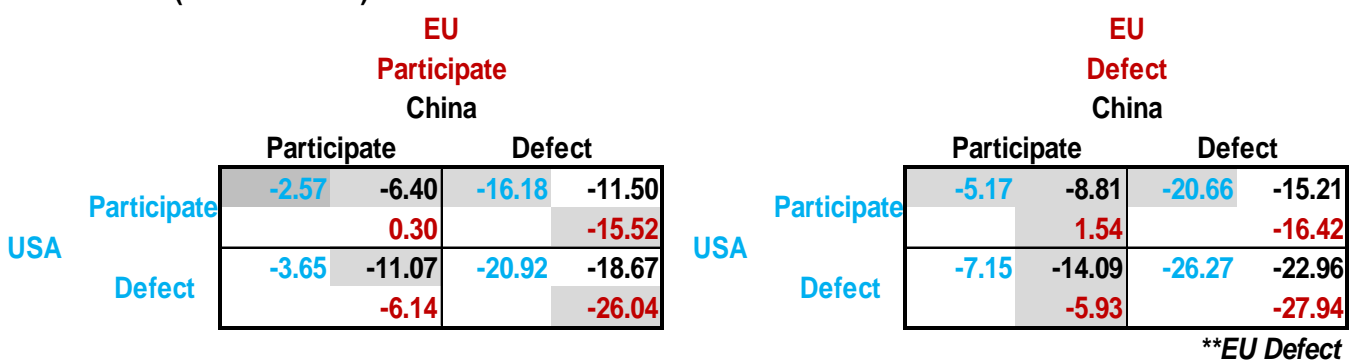

HIGH Scenario (in Trillion USD)
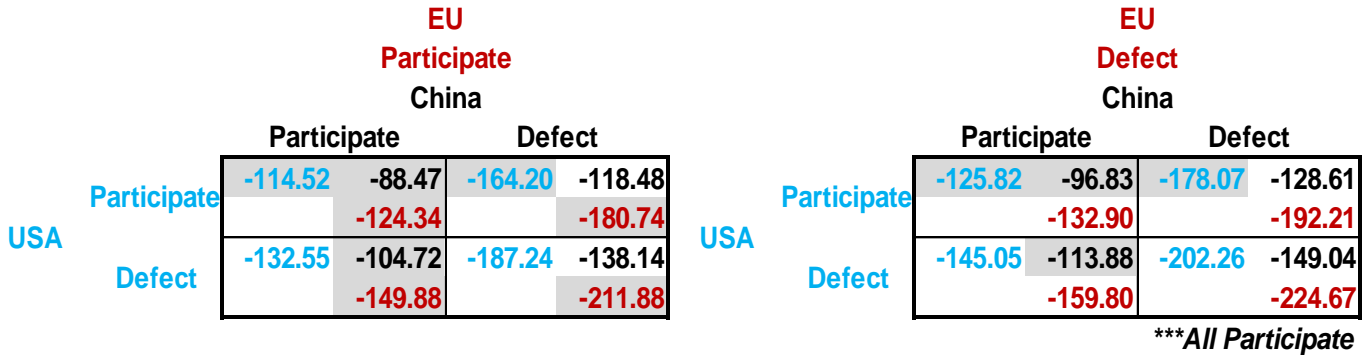

Figure 11: Normal Form Static Games on Present Values for Five Countries (Summarised)

LOW SCENARIO (TRILLION USD)

\begin{tabular}{|r|l|r|r|}
\hline \multirow{2}{*}{ NO } & \multirow{2}{*}{ COUNTRY } & \multicolumn{2}{|c|}{ PARTICIPATION } \\
\cline { 3 - 4 } & & PARTICIPATE & \multicolumn{1}{|c|}{ DEFECT } \\
\hline 1 & US & 8.29 & 10.73 \\
\hline 2 & China & 2.41 & 6.25 \\
\hline 3 & EU & 9.58 & 12.49 \\
\hline 4 & Indonesia & -0.26 & 0.14 \\
\hline 5 & Australia & -0.28 & 0.06 \\
\hline
\end{tabular}

HIGH SCENARIO (TRILLION USD)

\begin{tabular}{|r|l|r|r|}
\hline \multirow{2}{*}{ NO } & \multirow{2}{*}{ COUNTRY } & \multicolumn{2}{|c|}{ PARTICIPATION } \\
\cline { 3 - 4 } & & PARTICIPATE & DEFECT \\
\hline 1 & US & -178.07 & -202.26 \\
\hline 2 & China & -113.88 & -149.04 \\
\hline 3 & EU & -211.90 & -224.69 \\
\hline 4 & Indonesia & -3.74 & -3.43 \\
\hline 5 & Australia & -1.59 & -1.27 \\
\hline
\end{tabular}

Source: Estimation as described in the text
BEST SCENARIO (TRILLION USD)

\begin{tabular}{|r|l|r|r|}
\hline \multirow{2}{*}{ NO } & \multirow{2}{*}{ COUNTRY } & \multicolumn{2}{|c|}{ PARTICIPATION } \\
\cline { 3 - 4 } & & PARTICIPATE & DEFECT \\
\hline 1 & US & -20.66 & -26.27 \\
\hline 2 & China & -14.09 & -22.96 \\
\hline 3 & EU & -26.04 & -27.94 \\
\hline 4 & Indonesia & -0.91 & -0.54 \\
\hline 5 & Australia & -0.51 & -0.17 \\
\hline
\end{tabular}


Figure 12: The Scale of Side Payments from China, the USA and the EU Sufficient to Induce Universal Participation

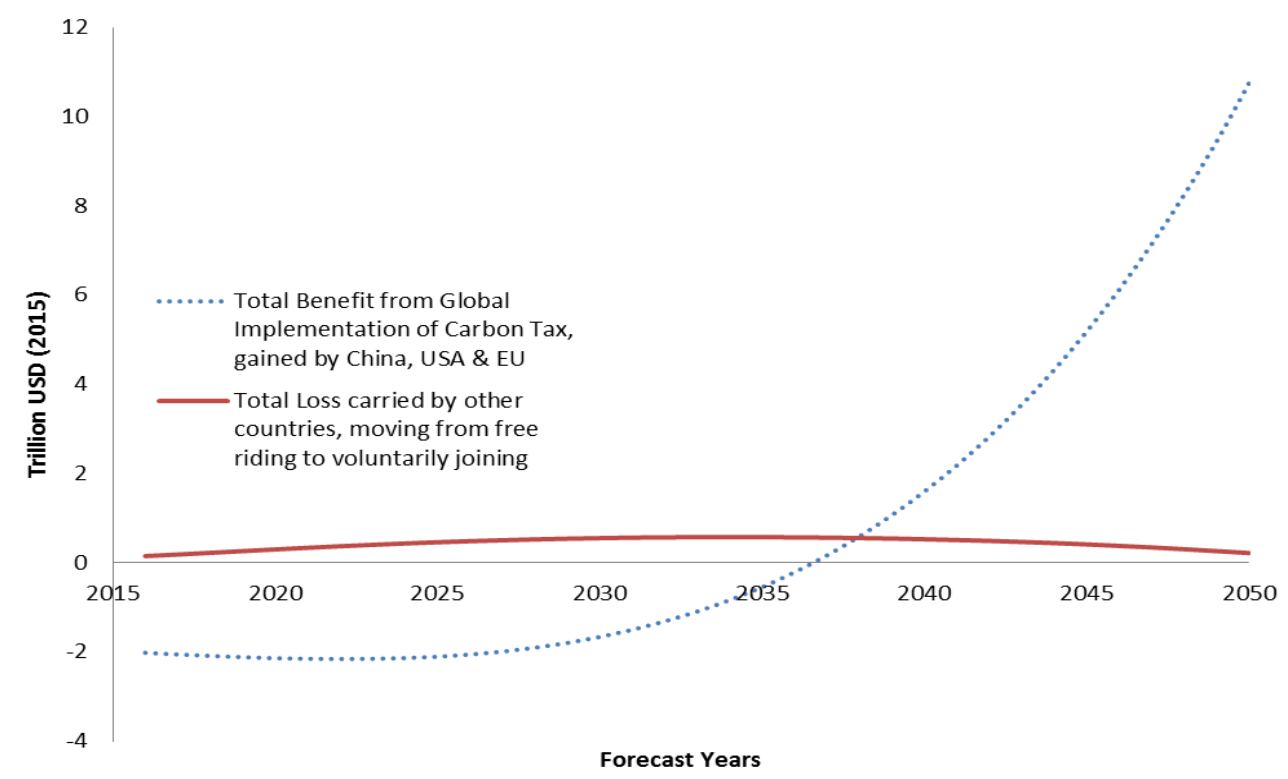

Source: Estimation as described in the text.

Figure 13: Estimated Net Welfare Benefit due to Unilateral Implementation of the Carbon Tax for China, USA, and EU

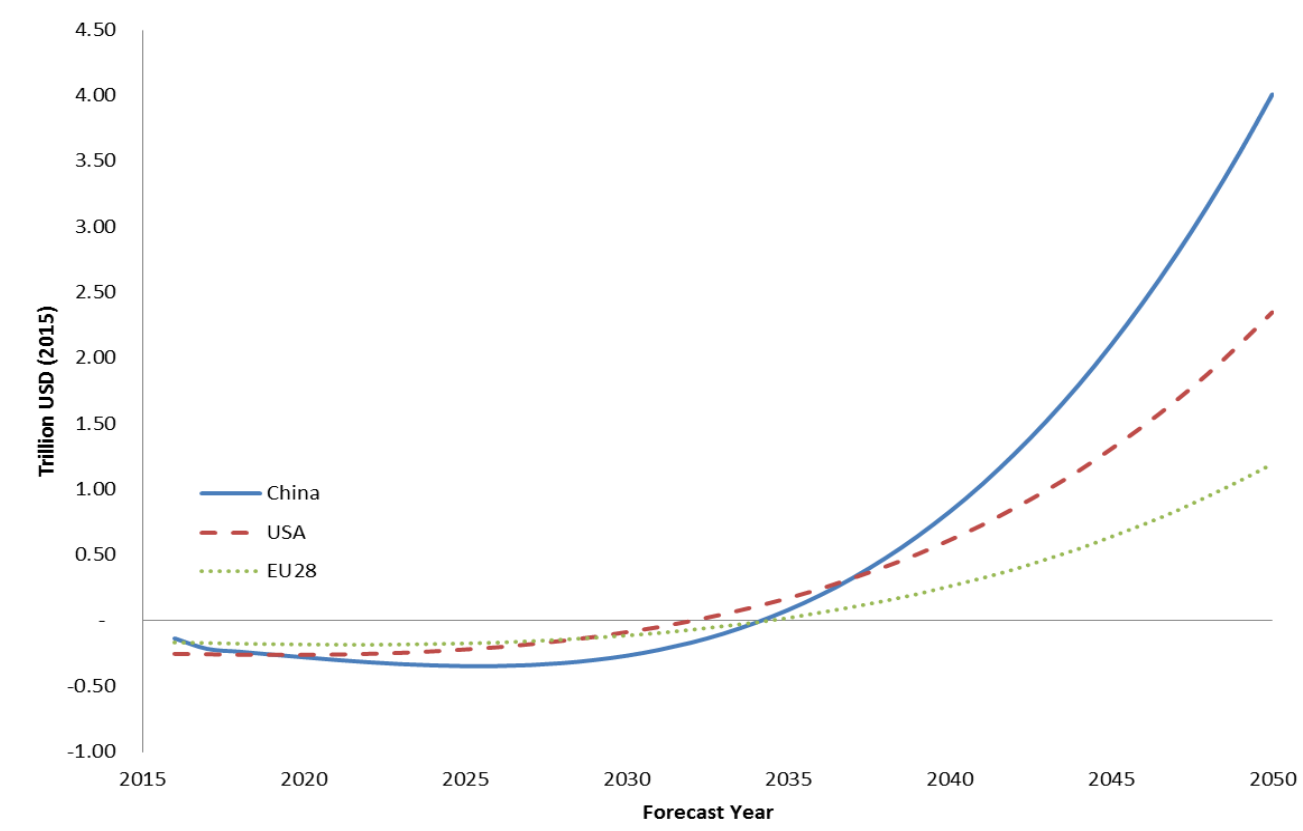

Source: Estimation as described in the text. 


\section{TABLES}

Table 1: IPCC Temperature Scenarios and Estimated Temperature Changes

\begin{tabular}{|c|c|c|c|c|c|c|c|}
\hline \multirow{2}{*}{$\begin{array}{c}\text { Emission } \\
\text { (GT) in } \\
2050 / \\
\text { Lower } \\
\text { Border }\end{array}$} & \multirow{2}{*}{$\begin{array}{c}\text { IPCC } \\
\text { (GHG } \\
\text { scenario) }\end{array}$} & \multirow{2}{*}{$\begin{array}{c}\text { IPCC } \\
\text { Atmospheric } \\
\text { Concentration } \\
\text { (PPM) }\end{array}$} & \multirow{2}{*}{$\begin{array}{c}\text { IPCC Best } \\
\text { Temperature } \\
\text { Estimate } \\
\left({ }^{\circ} \mathrm{C}\right)\end{array}$} & \multirow{2}{*}{$\begin{array}{c}\text { IPCC } \\
\text { Likely } \\
\text { Uncertainty } \\
\text { Range } \\
\left({ }^{\circ} \mathrm{C}\right)\end{array}$} & \multicolumn{3}{|c|}{$\begin{array}{c}\text { Developed Temperature } \\
\text { Estimate }\end{array}$} \\
\hline & & & & & $\begin{array}{c}\text { Low } \\
\text { Estimate } \\
\left({ }^{\circ} \mathrm{C}\right)\end{array}$ & $\begin{array}{c}\text { Best } \\
\text { Estimate } \\
\left({ }^{\circ} \mathrm{C}\right)\end{array}$ & $\begin{array}{c}\text { High } \\
\text { Estimate } \\
\left({ }^{\circ} \mathrm{C}\right)\end{array}$ \\
\hline 90 & A1F1 & $660-790$ & 4.0 & $2.4-6.4$ & 2.4 & 4.0 & 6.4 \\
\hline 80 & A2 & $570-660$ & 3.0 & $2.0-5.4$ & 2.0 & 3.0 & 5.4 \\
\hline 70 & A1B & $485-570$ & 2.8 & $1.7-4.4$ & 1.7 & 2.0 & 4.4 \\
\hline 60 & $\mathrm{~A} 1 \mathrm{~T}$ & $440-485$ & 2.4 & $1.4-3.8$ & 1.4 & 1.5 & 3.8 \\
\hline 37.2 & - & & - & - & 0.0 & 0.0 & 0.0 \\
\hline
\end{tabular}

Source: IPCC Synthesis Report (2007).

Table 2: Studies on Temperature and Welfare Impacts

\begin{tabular}{rlcc}
\hline No & \multicolumn{1}{c}{ Literature } & $\begin{array}{c}\text { Temperature } \\
\text { Rise }\left({ }^{\mathbf{0}} \mathbf{C}\right)\end{array}$ & $\begin{array}{c}\text { Welfare Effect } \\
(\boldsymbol{\%} \text { Global GDP })\end{array}$ \\
\hline 1 & Nordhaus (1994a) & 3.0 & -4.8 \\
2 & Nordhaus (1994b) & 3.0 & -1.3 \\
3 & Fankhauser (2013) & 2.5 & -1.4 \\
4 & Hope (2006) & 2.5 & 0.9 \\
5 & Rehdanz \& Maddison (2005) & 1.0 & -0.4 \\
6 & Nordhaus \& Yang (1996) & 2.5 & -1.7 \\
7 & Plambeck \& Hope (1996) & 2.5 & 2.5 \\
8 & Nordhaus (2006) & 2.5 & -0.9 \\
9 & Tol (1995) & 2.5 & 1.9 \\
10 & Nordhaus \& Boyer (2003) & 2.5 & 1.5 \\
11 & Mendelsohn et al. (2000a) & 2.5 & 0.0 \\
12 & Mendelsohn et al. (2000b) & 2.5 & 0.1 \\
13 & Tol (2002a) & 1.0 & 2.3 \\
14 & Tol (2002b) & 1.0 & 3.0 \\
15 & Maddison (2003) & 2.5 & -0.1 \\
\hline
\end{tabular}

Table 3: Regional to Global Benefit Ratios

\begin{tabular}{llrrrrrr}
\hline \multirow{2}{*}{ No } & \multirow{2}{*}{ COUNTRY/ REGION } & \multicolumn{5}{c}{ Temperature Rising } & \multirow{2}{*}{ AVERAGE } \\
\cline { 3 - 7 } & & $\mathbf{+ 1}^{\mathbf{0}} \mathbf{C}$ & $\mathbf{+ 2}^{\mathbf{0}} \mathbf{C}$ & $\mathbf{+ 3}^{\mathbf{0}} \mathbf{C}$ & $\mathbf{+ 4}^{\mathbf{0}} \mathbf{C}$ & $\mathbf{+ 5}^{\mathbf{0}} \mathbf{C}$ & \\
\hline 1 & Indonesia & 0.36 & 0.82 & 1.14 & 1.10 & 0.98 & 0.88 \\
2 & Singapore & 0.08 & 0.14 & 0.18 & 0.17 & 0.15 & 0.14 \\
3 & Malaysia & 0.19 & 0.32 & 0.41 & 0.38 & 0.34 & 0.33 \\
4 & Other ASEAN & 0.33 & 0.57 & 0.73 & 0.70 & 0.63 & 0.59 \\
5 & Other Asia & 0.88 & 1.16 & 1.34 & 1.29 & 1.21 & 1.17 \\
6 & Australia & 0.20 & 0.23 & 0.25 & 0.25 & 0.25 & 0.24 \\
7 & New Zealand \& Oceania & 0.09 & 0.07 & 0.07 & 0.07 & 0.07 & 0.07 \\
8 & China (PRC) & 3.97 & 3.82 & 3.79 & 3.79 & 3.80 & 3.83 \\
9 & Japan & 0.76 & 0.77 & 0.85 & 0.94 & 1.02 & 0.87 \\
\hline
\end{tabular}




\begin{tabular}{llrrrrrr}
\hline \multirow{2}{*}{ No } & \multirow{2}{*}{ COUNTRY/ REGION } & \multicolumn{5}{c}{ Temperature Rising } & \multirow{2}{*}{ AVERAGE } \\
\cline { 3 - 7 } & & $\mathbf{+ 1}^{\mathbf{0}} \mathbf{C}$ & $\mathbf{+ 2}^{\mathbf{0}} \mathbf{C}$ & $\mathbf{+ 3}^{\mathbf{0}} \mathbf{C}$ & $\mathbf{+ 4}^{\mathbf{0}} \mathbf{C}$ & $\mathbf{+ 5}^{\mathbf{0}} \mathbf{C}$ & \\
\hline 10 & Korea & 0.18 & 0.18 & 0.18 & 0.20 & 0.21 & 0.19 \\
11 & India & 1.74 & 2.32 & 2.68 & 2.52 & 2.31 & 2.32 \\
12 & Brazil & 0.37 & 0.58 & 0.75 & 0.81 & 0.81 & 0.66 \\
13 & USA & 2.76 & 2.50 & 2.34 & 2.29 & 2.35 & 2.45 \\
14 & Canada & 0.41 & 0.17 & 0.01 & 0.04 & 0.09 & 0.14 \\
15 & Other America & 0.85 & 1.64 & 1.87 & 1.88 & 1.75 & 1.60 \\
16 & EU_28 & 4.70 & 2.75 & 1.50 & 1.70 & 2.16 & 2.56 \\
17 & Russia & 0.62 & 0.28 & 0.05 & 0.08 & 0.16 & 0.24 \\
18 & FTA Europe & 0.15 & 0.08 & 0.04 & 0.04 & 0.06 & 0.07 \\
19 & Ex. Soviet Union \& Other EU & 0.43 & 0.29 & 0.20 & 0.21 & 0.24 & 0.27 \\
20 & Middle East & 1.24 & 1.15 & 1.10 & 1.07 & 1.06 & 1.13 \\
21 & Africa & 0.69 & 1.18 & 1.53 & 1.47 & 1.35 & 1.24 \\
\hline
\end{tabular}

Source: Estimation as described in the text.

Table 4: Estimated Average Global Welfare Effect from Emission Abatement by Regions and Regional Groupings, Percentage of GDP Deviation

\begin{tabular}{|c|c|c|c|c|c|c|c|c|}
\hline \multirow[t]{2}{*}{ No } & \multirow[t]{2}{*}{$\begin{array}{l}\text { Selected Scenario } \\
\text { Carbon Tax } \\
\text { Implementation }\end{array}$} & \multirow{2}{*}{$\begin{array}{c}\text { Global } \\
\text { Emission } \\
(\text { GT })\end{array}$} & \multicolumn{3}{|c|}{ 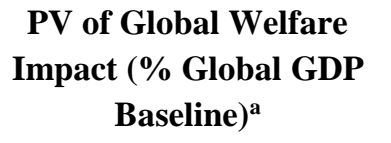 } & \multicolumn{3}{|c|}{$\begin{array}{c}\text { PV Participation Cost } \\
(\% \text { Country GDP } \\
{\text { Baseline })^{\mathrm{b}}}^{(\%)}\end{array}$} \\
\hline & & & Low & Best & High & CHN & USA & $\overline{\mathbf{E U}}$ \\
\hline 1 & Global (All Countries) & 64.90 & 2.02 & 1.77 & -11.40 & -0.84 & -0.57 & 0.19 \\
\hline 2 & US, China, EU (Big Three) & 87.35 & 0.16 & -8.96 & -37.80 & -2.76 & -0.64 & -0.17 \\
\hline 3 & US China & 89.18 & -0.12 & -10.33 & -40.64 & -3.04 & -0.70 & 0.42 \\
\hline 4 & China EU & 90.08 & -0.28 & -11.03 & -42.07 & -3.13 & 0.04 & -0.45 \\
\hline 5 & US EU & 95.01 & -1.18 & -15.17 & -50.36 & 0.65 & -0.62 & -0.31 \\
\hline 6 & China & 92.65 & -0.72 & -13.12 & -46.29 & -3.41 & -0.02 & 0.14 \\
\hline 7 & USA & 96.80 & -1.55 & -16.79 & -53.55 & 0.37 & -0.68 & 0.28 \\
\hline 8 & EU & 98.47 & -1.92 & -18.38 & -56.62 & 0.28 & 0.06 & -0.59 \\
\hline 9 & NONE & 100.28 & -2.32 & -20.18 & -60.05 & 0.00 & 0.00 & 0.00 \\
\hline
\end{tabular}

\footnotetext{
${ }^{\mathrm{a}}$ These effects stem from reduction in global surface temperature change, due to mitigation.

$\mathrm{b}$ The cost the implemented mitigation policy is a USD 20 Uniform Carbon Tax. Positive rate reflects benefit rate as free rider.

Source: Estimation as described in the text.
}

Table 5: Present Value of Improvement Relative to No Abatement Case, Percentage of 2015 Global GDP

\begin{tabular}{|c|c|c|c|c|c|c|c|c|}
\hline \multirow[t]{2}{*}{ No } & \multirow[t]{2}{*}{$\begin{array}{l}\text { Selected Scenario Carbon } \\
\text { Tax Implementation }\end{array}$} & \multirow[t]{2}{*}{$\begin{array}{c}\text { Global } \\
\text { Emission } \\
(\text { GT })\end{array}$} & \multicolumn{3}{|c|}{$\begin{array}{c}\text { PV Global Welfare Impact } \\
\text { (Trillion USD) }\end{array}$} & \multicolumn{3}{|c|}{$\begin{array}{c}\text { Percentage Improvement } \\
\text { from No Abatement Case } \\
\text { Relative to Baseline GDP } \\
\text { Value } \\
\end{array}$} \\
\hline & & & Low & Best & High & Low & Best & High \\
\hline 1 & NONE (No Abatement) & 100.28 & -1.41 & -12.24 & -36.43 & 0.00 & 0.00 & 0.00 \\
\hline 2 & Global (All Countries) & 64.90 & 1.23 & 1.08 & -6.92 & 4.34 & 21.95 & 48.65 \\
\hline
\end{tabular}




\begin{tabular}{|c|c|c|c|c|c|c|c|c|}
\hline \multirow[t]{2}{*}{ No } & \multirow[t]{2}{*}{$\begin{array}{l}\text { Selected Scenario Carbon } \\
\text { Tax Implementation }\end{array}$} & \multirow[t]{2}{*}{$\begin{array}{c}\text { Global } \\
\text { Emission } \\
(\text { GT) }\end{array}$} & \multicolumn{3}{|c|}{$\begin{array}{l}\text { PV Global Welfare Impact } \\
\text { (Trillion USD) }\end{array}$} & \multicolumn{3}{|c|}{$\begin{array}{c}\text { Percentage Improvement } \\
\text { from No Abatement Case } \\
\text { Relative to Baseline GDP } \\
\text { Value } \\
\end{array}$} \\
\hline & & & Low & Best & High & Low & Best & High \\
\hline 3 & US, China, EU (Big Three) & 87.35 & 0.10 & -5.44 & -22.93 & 2.48 & 11.21 & 22.25 \\
\hline 4 & Big Three + Indonesia & 86.42 & 0.18 & -5.03 & -22.08 & 2.62 & 11.87 & 23.65 \\
\hline 5 & Big Three + Other ASEAN & 86.66 & 0.16 & -5.14 & -22.30 & 2.59 & 11.70 & 23.29 \\
\hline 6 & Big Three + Australia & 86.84 & 0.15 & -5.21 & -22.46 & 2.56 & 11.58 & 23.02 \\
\hline 7 & Big Three + Japan & 86.91 & 0.14 & -5.24 & -22.53 & 2.55 & 11.53 & 22.92 \\
\hline 8 & Big Three + India & 80.42 & 0.65 & -2.71 & -16.98 & 3.39 & 15.71 & 32.06 \\
\hline 9 & Big Three + Russia & 84.32 & 0.36 & -4.17 & -20.22 & 2.91 & 13.31 & 26.72 \\
\hline 10 & Big Three + Middle East & 85.22 & 0.29 & -4.53 & -21.01 & 2.79 & 12.70 & 25.42 \\
\hline 11 & Big Three + New Zealand & 87.31 & 0.10 & -5.42 & -22.90 & 2.49 & 11.24 & 22.31 \\
\hline 12 & Big Three + Brazil & 87.21 & 0.11 & -5.38 & -22.80 & 2.50 & 11.31 & 22.46 \\
\hline 13 & Big Three + Korea & 86.80 & 0.15 & -5.20 & -22.43 & 2.56 & 11.61 & 23.08 \\
\hline 14 & Big Three + Canada & 86.93 & 0.14 & -5.25 & -22.55 & 2.54 & 11.51 & 22.89 \\
\hline 15 & Big Three + Latin Americas & 86.25 & 0.20 & -4.96 & -21.93 & 2.65 & 11.99 & 23.91 \\
\hline 16 & Big Three + Other Asia & 85.90 & 0.23 & -4.81 & -21.61 & 2.70 & 12.24 & 24.43 \\
\hline 17 & Big Three + FTA Europe & 87.32 & 0.10 & -5.42 & -22.90 & 2.49 & 11.23 & 22.30 \\
\hline 18 & Big Three +Ex. Soviet Union & 86.14 & 0.21 & -4.91 & -21.83 & 2.66 & 12.07 & 24.07 \\
\hline 19 & Big Three + Africa & 85.04 & 0.30 & -4.46 & -20.85 & 2.82 & 12.83 & 25.68 \\
\hline
\end{tabular}

Source: Estimation as described in the text.

Table 6: Cumulative Discounted Dollar Value of Net Welfare Benefit or Loss due to Uniform Tax (US\$ Trillions)

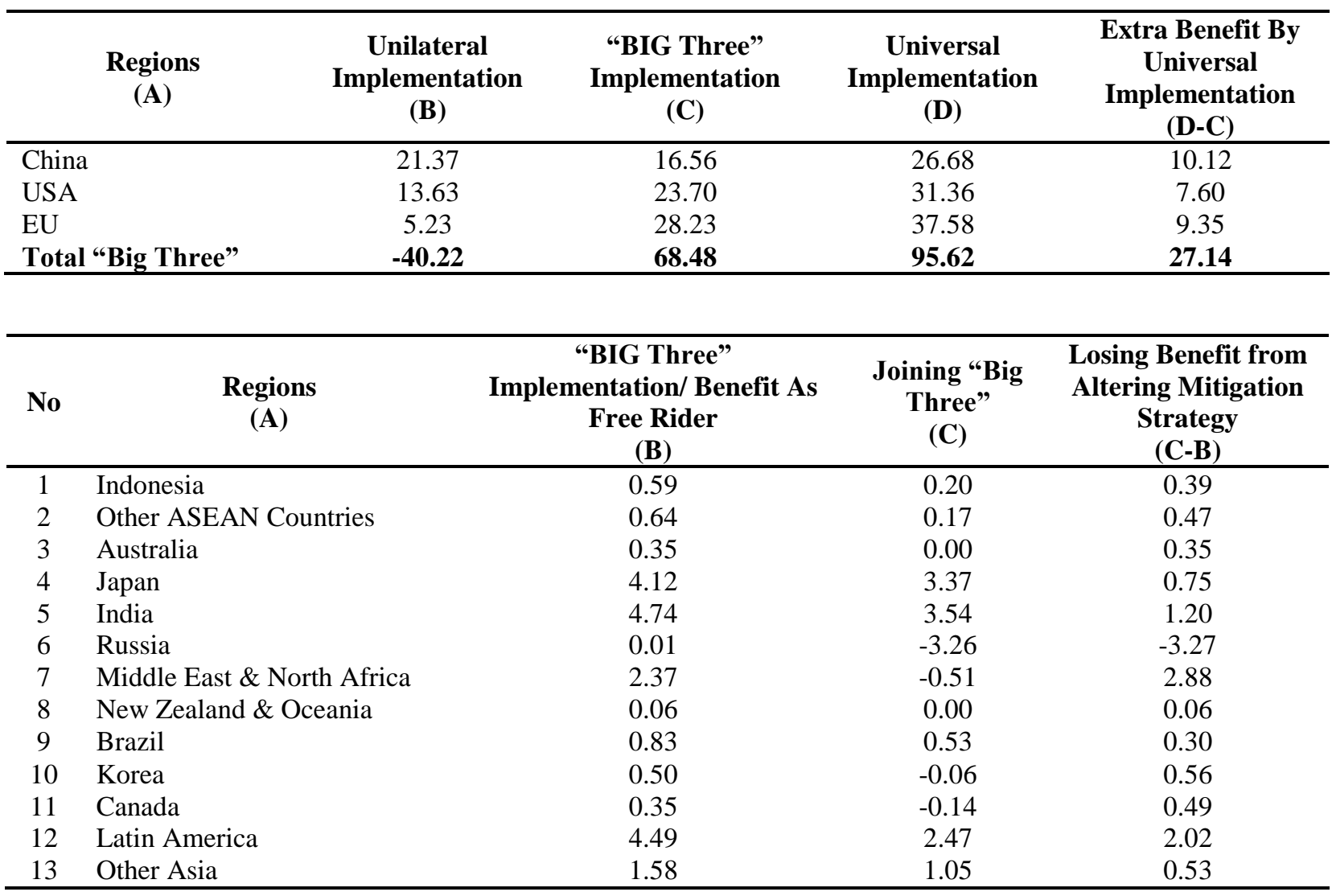




\begin{tabular}{llccc}
\hline No & $\begin{array}{c}\text { Regions } \\
(\mathbf{A})\end{array}$ & $\begin{array}{c}\text { "BIG Three" } \\
\text { Implementation/ Benefit As } \\
\text { Free Rider } \\
(\mathbf{B})\end{array}$ & $\begin{array}{c}\text { Joining "Big } \\
\text { Three" } \\
(\mathbf{C})\end{array}$ & $\begin{array}{c}\text { Losing Benefit from } \\
\text { Altering Mitigation } \\
\text { Strategy } \\
(\mathbf{C}-\mathbf{B})\end{array}$ \\
\hline 14 & FTA Europe & 0.15 & 0.05 & 0.10 \\
15 & Ex. Soviet Union & 0.32 & -0.75 & 1.07 \\
16 & Africa & 1.58 & 0.89 & 0.69 \\
& Total & $\mathbf{2 2 . 6 6}$ & $\mathbf{7 . 5 3}$ & $\mathbf{1 5 . 1 2}$ \\
\hline
\end{tabular}

Source: Estimation as described in the text. 